\title{
D-1 Dopamine Receptors in the Rat Brain: A Quantitative Autoradiographic Analysis
}

\author{
Ted M. Dawson, “ Donald R. Gehlert, ${ }^{\star, 1}$ R. Tyler McCabe, ${ }^{*}$ Allen Barnett, $\dagger$ and James K. Wamsley \\ *Departments of Psychiatry and Pharmacology, University of Utah School of Medicine, Salt Lake City, Utah \\ 84132, and †Pharmaceutical Research Division, Schering-Plough Corporation, Bloomfield, New Jersey 07003
}

\begin{abstract}
The distribution of dopamine D-1 receptors has been determined in the rat brain by a quantitative in vitro light-microscopic autoradiographic method. The binding of $\left[N\right.$-methyl- $\left.{ }^{3} \mathrm{H}\right]-$ SCH 23390 to slide-mounted tissue sections takes place with characteristics expected of a substance that recognizes D-1 receptors. The binding is saturable, has high affinity, and exhibits an appropriate pharmacology and stereospecificity in several discrete microscopic brain regions as determined by quantitative autoradiography. The highest density of D-1 receptors occurs in the caudate-putamen, accumbens nucleus, olfactory tubercle, and the substantia nigra pars reticulata. High concentrations of D-1 receptors were associated with the intercalated and medial nuclei of the amygdala, entopeduncular nucleus, and major island of Calleja. Furthermore, moderate to low concentrations were observed in several other structures, such as the frontal cortex, subthalamic nucleus, and several thalamic, hypothalamic, and hippocampal areas. The distribution of D-1 receptors correlates very well with projection areas of dopaminergic pathways. This technique furnishes a powerful assay for the accumulation of detailed pharmacologic and anatomical data about D-1 receptors, and the results suggest possible CNS sites of action of D-1 dopamine receptor selective compounds.
\end{abstract}

Pharmacological, biochemical, anatomical, and physiological studies have indicated that there are multiple receptors for dopamine (see for review Creese and Leff, 1982; Creese et al., 1983; Kebabian and Calne, 1979; Stoof and Kebabian, 1984). Dopamine type-1 (D-1) receptors are associated with stimulation of adenylate cyclase on agonist activation (Kebabian and Calne, 1979). Dopamine type-2 (D-2) receptors mediate either the inhibition of adenylate cyclase (Cote et al., 1981; Onali et al., 1981, 1984) or are unassociated with the enzyme (Kebabian and Calne, 1979). D-2 receptors have been extensively characterized by radioligand binding studies using ${ }^{3} \mathrm{H}$-spiperone (Creese et al., 1977; Fields et al., 1977) and the selective D-2 antagonist ${ }^{3} \mathrm{H}$-sulpiride (O'Connor and Brown, 1982; Theodorou et al., 1979; Woodruff and Freedman, 1981). D-1 receptors have been characterized using ${ }^{3} \mathrm{H}$-cis-(Z)-flupenthixol (Huff and Molinoff, 1985; Hyttel, 1978a, b; Murrin, 1983) and ${ }^{3} \mathrm{H}-$ cis-(Z)-piflutixol (Hyttel, 1981), but both compounds show similar affinities for the D-1 and D-2 receptors and a high degree

\footnotetext{
Received Oct. 28, 1985; revised Jan. 30, 1986; accepted Feb. 5, 1986.

We wish to thank Margaret Long and Linda Miller for their excellent secretarial assistance. This work was supported by grants from the Public Health Service (NS-22033) and the Scottish Rite Foundation. T.M.D. is a recipient of a P.M.A. Medical Student Research Fellowship.

Correspondence should be addressed to James K. Wamsley, Ph.D., Department of Psychiatry, University of Utah Medical Center, 50 North Medical Drive, Salt Lake City, Utah 84132.

${ }^{1}$ Present address: Section on Biochemical Pharmacology, Hypertension-Endocrine Branch, National Heart, Lung, and Blood Institute, National Institutes of Health, Bethesda, MD 20205.
}

Copyright (C) 1986 Society for Neuroscience $0270-6474 / 86 / 082352-14 \$ 02.00 / 0$ of nonspecific binding. As such, these two compounds are not suitable ligands for the study of D-1 receptors by autoradiography.

Recently, Iorio et al. (1983) described a putative neuroleptic, benzazepine SCH 23390 [(R)-(+)-8 chloro-2,3,4,5-tetrahydro3-methyl-5-phenyl-1H-3-benzazepine-7-ol hemimaleate], and postulated that it was a selective $D-1$ receptor antagonist based on its potent blockade of dopamine (DA)-stimulated adenylate cyclase, its weak displacement of ${ }^{3} \mathrm{H}$-spiperone binding, its failure to induce prolactinemia, and its selective displacement of ${ }^{3} \mathrm{H}$-piflutixol binding from striatal slices (Hyttel, 1983). A tritiated form of SCH 23390 has been determined to bind with stereospecificity, with high affinity, and in a saturable manner to receptor sites that have been characterized as the D-1 receptors (Billard et al., 1984). Therefore, ${ }^{3} \mathrm{H}-\mathrm{SCH} 23390$ has been designated as the most suitable ligand for investigations attempting to characterize the D-1 receptor.

In vitro autoradiographic techniques have previously been used to localize DA receptors microscopically. Extensive studies have localized D-2 receptors using ${ }^{3} \mathrm{H}$-spiperone (Klemm et al., 1979; Murrin and Kuhar, 1979; Palacios and Wamsley, 1984; Palacios et al., 1981a), ${ }^{3} \mathrm{H}$-sulpiride (Gehlert and Wamsley, 1984, 1985; Jastrow et al., 1984), ${ }^{3} \mathrm{H}(-)$-DO7 10 (Sokoloff et al., 1985), and ${ }^{125}$ I-iodosulpride (Martres et al., 1985a, b); these investigations have demonstrated that the D-2 receptor is associated primarily with the tuberoinfundibular system, nigrostriatal system, periglomerular DA system of the olfactory complex, and, to a minor extent, the mesocortical and mesolimbic systems. Recently, we utilized ${ }^{3} \mathrm{H}-\mathrm{SCH} 23390$ (Dawson et al., 1985a), and Scatton and Dubois (1985) used ${ }^{3} \mathrm{H}-\mathrm{SKF} 38393$ to localize D-1 receptors to several mesocortical and mesolimbic system structures where the existence of DA terminals and receptors was suspected but could not be demonstrated with previously available radioligands.

In the present study, ${ }^{3} \mathrm{HI}-\mathrm{SCII} 23390$ was evaluated for its suitability and specificity as a D-1 receptor antagonist by using the quantitative technique of in vitro receptor autoradiography (Unnerstall et al., 1982; see for review Kuhar, 1985b). In addition, the regional distribution and density of D-1 dopamine receptors in discretc microscopic regions of the rat brain are described.

\section{Materials and Methods}

\section{Materials}

[ $N$-methyl- $\left.{ }^{3} \mathrm{H}\right]-\mathrm{SCH} 23390$ (specific activity, $72 \mathrm{Ci} / \mathrm{mmol}$ ), SCH 23390 (R-enantiomer), cis-(Z)-piflutixol, trans-(E)-piflutixol were generous gifts from Schering-Plough Corp. (Bloomfield, NJ). Fluphenazine (New England Nuclear, Boston, MA), forskolin (Calbiochem-Behring Corp., La Jolla, CA), ketanserin (Janssen Pharmaceutica Inc., Piscataway, NJ), SKF 38393 (Smith Kline \& French Labs, Philadelphia, PA), ADTN and triprolidine (Burroughs Wellcome Co., Research Triangle Park, NC), Naloxone (Endo Laboratories Inc., Garden City, NJ), atropine (J. T. 
Baker Chemical Co., Phillipsburg, NJ), serotonin and propranolol (Sigma Chemical Co., St. Louis, MO), diazepam (Hoffman-LaRoche, Nutley, NJ), sulpiride (S.P.A. per l'industria chemica e. Pharmaceutica, Milan, Italy), and mcthyscrgide (Sandoz Inc., E. Hanover, NJ) were either purchased or were gifts from the manufacturers.

\section{Tissue preparation}

Male Sprague-Dawley rats (150-300 gm) were purchased from Simonsen Laboratories and kept under a controlled light-dark cycle and temperature until sacrificed by intracardial perfusion (while under deep chloroform anesthesia) with $0.9 \%$ saline. The brains were rapidly dissected from the skull and frozen by slow immersion into isopentane at $-80^{\circ} \mathrm{C}$. Sections $\left(10 \mu \mathrm{m}\right.$ thick) were cut on a Harris cryostat $\left(-18^{\circ} \mathrm{C}\right)$ microtome (Harris Manufacturing, N. Billerica, MA) and thaw-mounted onto cold chrome-alum/gelatin-coated microscope slides. The slidemounted tissue sections were then stored for short periods of time in a self-defrosting freezer $\left(-20^{\circ} \mathrm{C}\right)$.

\section{Biochemical investigations}

The dissociation, association, and saturation kinetics of ${ }^{3} \mathrm{H}-\mathrm{SCH} 23390$ binding to slide-mounted tissue sections were studied by exposing sections of forebrain, containing primarily striatum, to various rinse times ( $3 \mathrm{sec}$ to $20 \mathrm{~min}$ ), incubation times (1-60 min), and incubation concentrations (0.05-10.0 nM), respectively, in $50 \mathrm{~mm}$ Tris $\mathrm{HCl}$ buffer $(\mathrm{pH}$ 7.4) containing $120 \mathrm{mM} \mathrm{NaCl}, 5 \mathrm{mM} \mathrm{KCl}, 2 \mathrm{mM} \mathrm{CaCl}_{2}$, and $1 \mathrm{~mm}$ $\mathrm{MgCl}_{2}$. A concentration of $0.3 \mathrm{~nm}$ of ${ }^{3} \mathrm{H}-\mathrm{SCH} 23390$ was used in the dissociation and association experiments, and an incubation time of 30 min (followed by two 5 -min rinses in ice-cold buffer) was used in subsequent saturation experiments. Nonspecific binding was determined by incubating serial tissue sections in separate coplin jars under identical conditions, except for the additional presence of $10^{-6} \mathrm{M}$ unlabeled SCH 23390. The amount of radioactivity contained in these tissue sections was quantified by wiping the tissue from the slide with Whatman GF/B glass microfiber disks. The tissue-laden filters were then placed individually in scintillation vials, scintillation cocktail was added, and the radioactivity bound to the tissue section was determined by liquid scintillation counting. Dissociation, association, and saturation curves were plotted from the data obtained.

\section{Autoradiographic procedures}

The regional distribution of $\mathrm{D}-1$ receptors was determined by incubating serial sections of forebrain, brain stem, and spinal cord (cut at approximately $250 \mu \mathrm{m}$ intervals) for $30 \mathrm{~min}$ at room temperature in $50 \mathrm{~mm}$ Tris $\mathrm{HCl}$ (pH 7.4) containing $120 \mathrm{~mm} \mathrm{NaCl}, 5 \mathrm{~mm} \mathrm{KCl}, 2 \mathrm{~mm} \mathrm{CaCl}$, $1 \mathrm{mM} \mathrm{MgCl}_{2}$, and $1.0 \mathrm{nM}{ }^{3} \mathrm{H}-\mathrm{SCH} 23390$. Serial sections were also incubated in the same media, with the addition of $5 \times 10^{-6} \mathrm{M}$ fluphenazine or $10^{-6} \mathrm{M}$ unlabeled SCH 23390 , to produce autoradiograms representing nonspecific binding. The sections were then dipped in icecold buffer, followed by 25 -min rinses in fresh buffer. The buffer salts were removed by a rapid dip in ice-cold distilled water, and the sections were dried $(30 \mathrm{sec})$ by blowing cool, dry, filtered air over their surfaces.

Autoradiograms were generated by apposition of the labeled tissue sections to LKB Ultrofilm (LKB Instruments, Rockville, MD) in Wolf $\mathrm{X}$-ray cassettes. After a 3 or 6 week exposure period, the films were removed and developed. The autoradiograms produced by the labeled tissue sections were examined using a Leitz Orthoplan microscope or by examining photomicrographs of the latent images on the tritiumsensitive film taken with an Orthomat camera system attached to the Leitz microscope. Anatomical areas were identified and named according to Paxinos and Watson (1982). Cresyl violet staining of the tissue sections was performed in order to verify the anatomic areas identified from the autoradiograms.

In order to ensure that the autoradiographic grains were due to ${ }^{3} \mathrm{H}-$ SCH 23390 binding to D-1 receptors, saturation and displacement assays were performed in sections of rat brain through the prefrontal cortex, striatum, and substantia nigra. The saturation studies were executed on serial tissue sections using the conditions outlined above, except that the ${ }^{3} \mathrm{H}-\mathrm{SCH} 23390$ concentration was varied from 0.05 to $10.0 \mathrm{~nm}$. Competition studies were also carried out using the conditions outlined above, except that various concentrations of unlabeled $\mathrm{SCH}$ 23390 (R-enantiomer) $\left(10^{-6}-10^{-13} \mathrm{M}\right)$, fluphenazine $\left(10^{-5}-10^{-11} \mathrm{M}\right)$, SKF $38393\left(10^{-4}-10^{-10} \mathrm{M}\right)$, sulpiride $\left(10^{-4}-10^{-8} \mathrm{M}\right)$, methysergide $\left(10^{-4}\right.$ $\left.10^{-10} \mathrm{M}\right)$, ketanserin $\left(10^{-4}-10^{-10} \mathrm{M}\right)$, cis-(Z)-piflutixol $\left(10^{-5}-10^{-11} \mathrm{M}\right)$, or trans-(E)-piflutixol $\left(10^{-5}-10^{-11} \mathrm{M}\right)$ were added to the incubation me- dia. Micromolar concentrations of several pharmacologically unrelated compounds (atropine, diazepam, forskolin, naloxone, nomifensine, propranolol, 5-HT, and triprolidine) were added to the incubation media in order to determine their effects on ${ }^{3} \mathrm{H}-\mathrm{SCH} 23390$ binding. Autoradiograms were then generated, and the autoradiographic grain densities were quantitated as described below. This provided a means for plotting saturation isotherms and displacement curves from data obtained from several microscopic regions of the rat brain. Scatchard analysis was performed on the saturation data, yielding $K_{\mathrm{d}}$ 's and $B_{\max }$ 's for several areas. Competition curves, constructed from the densitometric data, were analyzed using an iterative, nonlinear, least-squares, curve-fitting computer program (Munson and Rodbard, 1980).

\section{Quantitation}

Analysis of the autoradiographic grain densities on the film (D-1 receptors) in corresponding tissue areas was accomplished using computer-assisted microdensitometric analysis. A DADS model 560 (Stahl Research, Rochester, NY) photometry system (an Oki computer interfaced with an MPV-Compact photometer attached to the Leitz microscope) was used for this purpose. Optical density values were converted into molar quantities of bound ligand by referencing a tritium-labeled polymer (Autoradiographic [ $\left.{ }^{3} \mathrm{H}\right]-$ Microscales; Amersham Corp., Arlington Heights, II). These standards are calibrated for the tritium concentration in gray-white matter areas according to the method of Unnerstall et al. (1982). Since beta-particles emitted by tritium have a relative low energy, tritium "quenching" tends to occur in arcas of high white matter content, resulting in varying degrees of autoradiographic efficiency over a tissue section (Kuhar and Unnerstall, 1985; Rainbow et al., 1984). This leads to an underestimation of the concentration of radioactivity in areas of high white matter density (Kuhar and Unnerstall, 1985; Rainbow et al., 1984). Values for total and nonspecific ${ }^{3} \mathrm{H}$ SCH 23390 binding were obtained for each region by averaging 5 readings over an individual area. Care was taken, when possible, to take readings from predominantly gray matter in order to minimize the underestimation of bound radioactivity. Results reported in this investigation are from at least 2 separate experiments involving tissue from 3 or more animals per experiment.

\section{Results}

\section{Properties of ${ }^{3} \mathrm{H}-\mathrm{SCH} 23390$ binding to striatal brain sections}

The dissociation rate of ${ }^{3} \mathrm{H}-\mathrm{SCH} 23390$ was evaluated first by incubating 2 sets of 6 sections for $20 \mathrm{~min}$ in $0.3 \mathrm{~nm}{ }^{3} \mathrm{H}-\mathrm{SCH}$ 23390 and then subjecting them to various rinse times. Two 5 -min rinses were determined to be optimal and provided the highest specific-to-nonspecific (signal-to-noise) ratio without significant loss in specific binding (Fig. $1 A$ ). A rate constant for dissociation was not calculated due to the high amount of total binding remaining at $20 \mathrm{~min}$.

Variation of the incubation time from 1 to $60 \mathrm{~min}$ (using the rinse time determined in the previous experiment) was performed to examinc the association rate of ${ }^{3} \mathrm{H}-\mathrm{SCH} 23390$ to striatal brain sections (Fig. $1 B$ ). An incubation time of $30 \mathrm{~min}$ was determined to be optimal. The association rate constant $\left(K_{+1}\right)$ was computed to be $0.015 \mathrm{~min}^{-1} \mathrm{nM}^{-1}$ using pseudo-firstorder kinetics (Weiland and Molinoff, 1981).

The binding of ${ }^{3} \mathrm{H}-\mathrm{SCH} 23390$ to brain sections was saturablc, specific, and of a high affinity (Fig. 1C). Scatchard analysis of the binding indicates a dissociation constant $\left(K_{\mathrm{d}}\right)$ of $1.86 \mathrm{nM}$ and a maximal number of binding sites $\left(B_{\max }\right)$ of $72.91 \mathrm{fmol} /$ $\mathrm{mg}$ tissue (Fig. 1D). These values are in agreement with those reported by Billard et al. (1984) for striatal membrane preparations. A Hill plot of these data yielded a slope of 0.97 , indicating that there was no cooperativity and that the binding was taking place to a single population of receptors. For routine autoradiographic studies, a concentration of $1 \mathrm{~nm}$ was chosen, which maintains "zone A" conditions. Using the parameters outlined above, $95-98 \%$ of ${ }^{3} \mathrm{H}-\mathrm{SCH} 23390$ binding to tissue sections was specific. Such low levels of nonspecific binding virtually ensure that essentially all of the visualized autoradiographic grains were due to specific ${ }^{3} \mathrm{H}-\mathrm{SCH} 23390$ binding. 
A

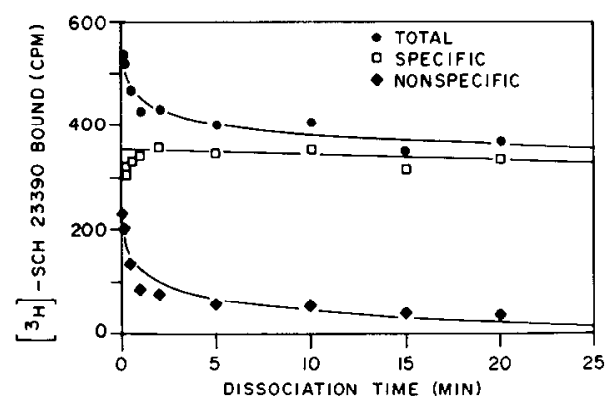

C

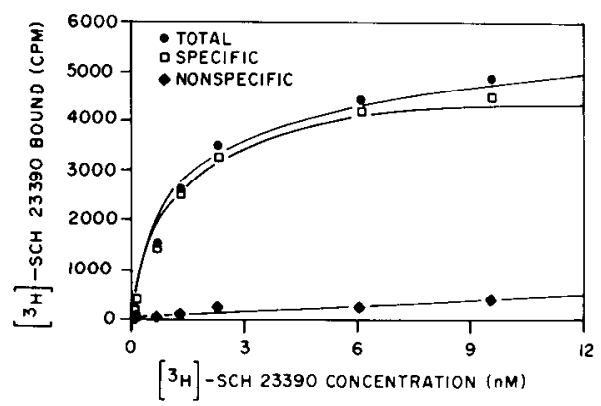

B

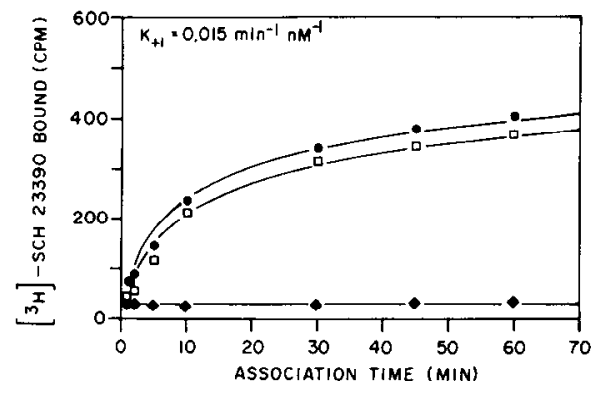

D

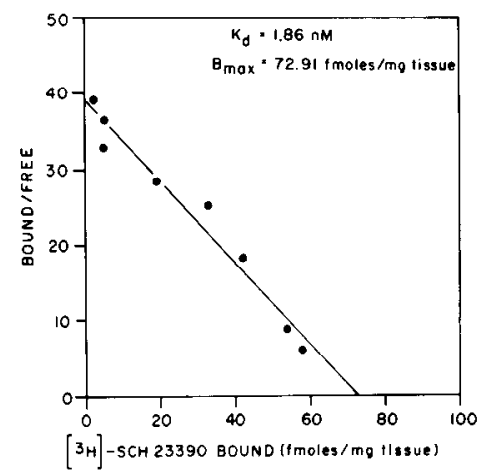

Figure 1. A, Dissociation analysis of ${ }^{3} \mathrm{H}-\mathrm{SCH} 23390$ binding to slide-mounted tissue sections. The binding procedure was performed as described in the text. After incubation for $20 \mathrm{~min}$ with $0.3 \mathrm{nM}{ }^{3} \mathrm{H}-\mathrm{SCH} 23390$, the incubation was stopped by infinite dilution in fresh, cold buffer for various times. These curves represent the mean of 2 separate experiments performed in triplicate. $B$, Equilibrium time course of ${ }^{3} \mathrm{H}-\mathrm{SCH} 23390$ binding. Binding of ${ }^{3} \mathrm{H}-\mathrm{SCH} 23390(0.3 \mathrm{nM})$ was carried out as described in the text. The incubation was stopped by immersion in fresh, cold buffer for 2 5-min rinses. These curves represent the average of 2 separate experiments performed in triplicate. The association rate constant was derived assuming pseudo-first-order kinetics. $C$, Saturation of ${ }^{3} \mathrm{H}-\mathrm{SCH} 23390$ binding in tissue sections. The tissue sections, in areas representing the striatum, were incubated with varying concentrations of ${ }^{3} \mathrm{H}-\mathrm{SCCH} 23390(0.05-10 \mathrm{nM})$ with or without $1 \mu \mathrm{M}$ cold SCH 23390 as described in the text. Binding of ${ }^{3} \mathrm{H}-\mathrm{SCH} 23390$ at each concentration was measured by liquid scintillation counting and fit to a hyperbolic curve by computer fitting. The data represent the mean of 2 separate experiments performed in triplicate. $D$, Scatchard plot of the specific binding of ${ }^{3} \mathrm{H}-\mathrm{SCH} 23390$ to slide-mounted tissue sections. Linear regression yielded a single component $(r=0.98)$ with a $K_{\mathrm{d}}$ (dissociation constant) of $1.86 \mathrm{nM}$ and a $B_{\max }$ of $72.91 \mathrm{fmol} / \mathrm{mg}$ tissue. A Hill plot of the data yielded a slope of 0.97 . Data are the average of 2 separate experiments performed in triplicate.

\section{Quantitative autoradiographic analysis of ${ }^{3} \mathrm{H}-\mathrm{SCH} 23390$ binding to brain sections}

To establish that the pharmacological specificity of ${ }^{3} \mathrm{H}-\mathrm{SCH}$ 23390 binding to tissue sections was similar to the binding in striatal membrane preparations, we evaluated the displacement of ${ }^{3} \mathrm{H}-\mathrm{SCH} 23390$ binding in several discrete microscopic regions of the brain by using several related and unrelated compounds. $K_{\mathrm{i}}$ values for several brain areas are reported in Table 1 . The most potent compound inhibiting ${ }^{3} \mathrm{H}-\mathrm{SCH} 23390$ binding was SCH 23390 itself, with a $K_{\mathrm{i}}$ ranging from 0.214 to 0.343 nM. $C i s-(Z)-P i f l u t i x o l$ inhibits specific binding by $50 \%$ at $0.274-$ $1.94 \mathrm{nM}$, depending on the brain area examined; this value is about 1000 times more potent than trans-(E)-piflutixol (Table 1). Of the other DA receptor antagonists tested, fluphenazine had a $K_{\mathrm{i}}$ ranging from 0.649 to $12.3 \mathrm{~nm}$ and sulpiride had a $k_{\mathrm{i}}$ of at least $10,000 \mathrm{nM}$. In contrast to the apparent single-site binding characteristics demonstrated with the DA antagonists, competition experiments performed using the selective D-1 agonist, SKF 38393, to displace ${ }^{3} \mathrm{H}-\mathrm{SCH} 23390$ binding was heterogeneous. The latter results were fit to a 1 -site model in several regions of the brain. However, the binding was susceptible to guanine nucleotide regulation (data not shown), suggesting that a high- and low-affinity agonist state exists for the D-1 receptor. The 5-HT antagonists methysergide and ketanserin had $K_{\mathrm{i}}$ 's ranging from 176 to $598 \mathrm{~nm}$ and from 110 to $2790 \mathrm{nM}$, respectively. Micromolar concentrations of atropine, diazepam, forskolin, naloxone, nomifensine, propranolol, 5-HT, and triprolidine showed little or no effect on the binding of ${ }^{3} \mathrm{H}-\mathrm{SCH} 23390$ to several rat brain areas.

Saturation studies performed in several regions of the rat brain and subsequently analyzed using quantitative autoradiography demonstrated saturable, high-affinity binding of ${ }^{3} \mathrm{H}-\mathrm{SCH} 23390$ to many brain structures; the $K_{\mathrm{d}}$ 's and $B_{\max }$ 's are reported in Table 2. A $K_{\mathrm{d}}$ of $2.9 \mathrm{~nm}$ and a $B_{\max }$ of $220.7 \mathrm{fmol} / \mathrm{mg}$ tissue were obtained in the caudate-putamen, and a $K_{\mathrm{d}}$ of $2.7 \mathrm{nM}$ and $B_{\max }$ of $186.2 \mathrm{fmol} / \mathrm{mg}$ tissue were obtained in the nucleus accumbens. These values are in close agreement with those obtained in slide-mounted tissue wipes through areas corresponding to the striatum. Hill plots of the data gave slopes that approached unity, indicating no cooperactivity and binding to a single population of receptors.

\section{Regional distribution of ${ }^{3} \mathrm{H}-\mathrm{SCH}-23390$ binding sites (D-1 receptors)}

The distribution of D-1 receptors exhibited a marked regional heterogeneity. The amount of ${ }^{3} \mathrm{H}-\mathrm{SCH} 23390$ bound (reported 
Table 1. Affinities for ' $\mathrm{H}-\mathrm{SCH} \mathbf{2 3 3 9 0}$ binding to rat brain areas by various compounds as determined by quantitative autoradiography

\begin{tabular}{|c|c|c|c|c|c|c|}
\hline \multirow[b]{2}{*}{ Compound } & \multicolumn{6}{|c|}{ Affinity, $k_{\mathrm{i}}(\mathrm{nM})$} \\
\hline & $\begin{array}{l}\text { Accumbens } \\
\text { nucleus }\end{array}$ & $\begin{array}{l}\text { Caudate } \\
\text { putamen }\end{array}$ & $\begin{array}{l}\text { Olfactory } \\
\text { tubercle }\end{array}$ & Claustrum & $\begin{array}{l}\text { Frontal cortex } \\
\text { lamina VI }\end{array}$ & $\begin{array}{l}\text { Substantia } \\
\text { nigra } \\
\text { reticulata }\end{array}$ \\
\hline Fluphenazine & 11.2 & 8.91 & 1.89 & 11.2 & 0.649 & 12.3 \\
\hline cis-(Z)-Piflutixol & 1.09 & 1.01 & 1.94 & 0.274 & 0.617 & 0.904 \\
\hline trans-(E)-Piflutixol & 1210 & 1050 & 1040 & 85 & 1620 & 1520 \\
\hline \multicolumn{7}{|l|}{ Dopamine agonists } \\
\hline SKF 38393 & 56.8 & 7.99 & 41.6 & - & 17.6 & 39.0 \\
\hline \multicolumn{7}{|l|}{ 5-HT antagonists } \\
\hline Ketanserin & 2790 & 541 & 582 & 307 & 110 & 307 \\
\hline Methysergide & 598 & 362 & 301 & 272 & 176 & 272 \\
\hline
\end{tabular}

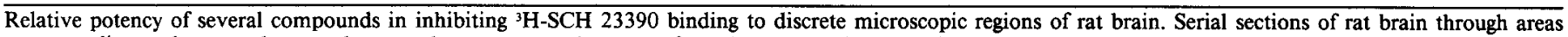

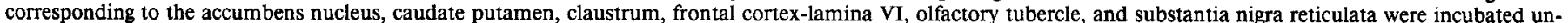

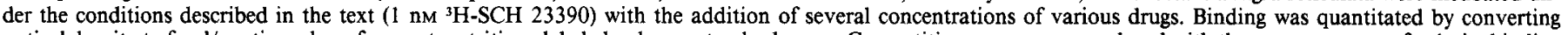

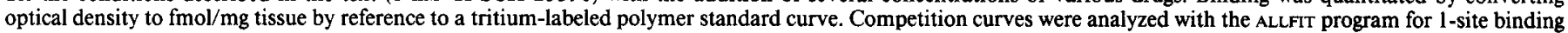

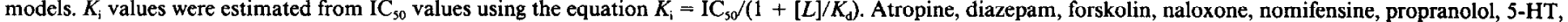

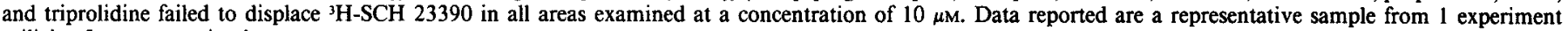
utilizing 3 separate animals.

as $\mathrm{fmol} / \mathrm{mg}$ tissue) and the amount of binding relative to the most dense area of D-1 receptors, the caudate-putamen nucleus (expressed as a percentage of this value), are summarized in Table 3. Autoradiographic grain densities, indicating the presence of D-1 receptor binding, were ranked by arbitarily assigning very high densities as those being greater than $50 \mathrm{fmol} / \mathrm{mg}$ tissue, high being between 25 and $50 \mathrm{fmol} / \mathrm{mg}$ tissue, low between 5 and $10 \mathrm{fmol} / \mathrm{mg}$ tissue, and very low being less than $5 \mathrm{fmol} / \mathrm{mg}$ tissue. The distribution of the D-1 receptors is illustrated in the photographic atlas presented in Figures 2-5. The discussion of the distribution of D-1 receptors that follows is presented according to the brain subdivision in which they occur.

\section{Cortex}

Low to very low concentrations of D-1 receptors were found in the cortex. These sites were localized to all arcas and laminae of the cerebral cortex. The anteromedial and suprarhinal systems of the prefrontal cortex contain low to very low numbers of D-1 receptors, but the amount was approximately 5 times greater than that demonstrated in the other laminae (Fig. 2). In examining the laminar distribution of ${ }^{3} \mathrm{H}-\mathrm{SCH} 23390$ binding sites within the neocortex, we found a differential distribution, with the most superficial layers exhibiting almost $50 \%$ fewer D-1 receptor sites than the deeper layers. The highest density of binding sites within the cortical parenchyma was localized to a continuous band that includes lamina VI and parts of lamina $\mathrm{V}$. There is an increasing rostrocaudal gradient of receptor density within this band. The anterior cingulate cortex exhibited this gradation (lamina VI greater than lamina I) in receptor density, whereas within the posterior cingulate and retrosplenial cortices there was a uniform receptor distribution. The entorhinal and primary olfactory cortices contained, in general, higher concentrations of D-1 receptors than did the other cortices. The temporal cortex also exhibited a differential distribution within the laminae and contained approximately twice as many receptors as the other laminae in the neocortex (Figs. 2-5).

\section{Basal ganglia}

In the basal ganglia, marked differences in the amount of ${ }^{3} \mathrm{H}$ SCH 23390 binding were noted. The head, body, and tail of the caudate-putamen nucleus presented very high concentrations of ${ }^{3} \mathrm{H}-\mathrm{SCH} 23390$ binding sites, the ventral pallidum presented moderate concentrations, and the globus pallidus had low concentrations (Figs. 3 and 4).

\section{Septal area}

Very high concentrations of D-1 receptors were noted in association with the accumbens nucleus. The dorsal part of the lateral septal nucleus had low concentrations of D-1 receptors, and the intermediate part of the lateral septal nucleus and the medial septal nucleus contained very low numbers of $D-1$ receptors (Fig. 3A).

\section{Amygdala}

As can be seen in Figure 4, $B$ and $C$, the amount of binding varicd widely in the amygdaloid nuclear complex, with the intercalated and ventral part of the basolateral nucleus exhibiting

Table 2. Affinities $\left(K_{d}\right)$ and maximal number of binding sites $\left(B_{\max }\right)$ for several rat brain structures as determined by quantitative autoradiography

\begin{tabular}{llc} 
Area & $\begin{array}{l}K_{\mathrm{d}} \\
(\mathrm{nM})\end{array}$ & $\begin{array}{l}B_{\max } \\
(\mathrm{fmol} / \mathrm{mg} \\
\text { tissue) }\end{array}$ \\
\hline Accumbens nucleus & 2.7 & 186.2 \\
Caudate-putamen & 2.9 & 220.7 \\
Claustrum & 3.7 & 94.4 \\
Endopiriform nucleus & 5.0 & 75.4 \\
Frontoparietal cortex lamina VI & 1.9 & 7.8 \\
Olfactory tubercle & 2.9 & 203.0 \\
\hline
\end{tabular}

Dissociation constants $\left(K_{d}\right)$ and maximal binding capacities $\left(B_{\max }\right)$ of ${ }^{3} \mathrm{H}-\mathrm{SCH}$ 23390 to discrete microscopic regions of the brain were determined by performing Scatchard analysis. Saturation isotherms were generated by incubating serial sections of rat brain in varying concentrations $(0.5-10.0 \mathrm{nM})$ of ${ }^{3} \mathrm{H}-\mathrm{SCH} 23390$. The autoradiograms were analyzed utilizing computer-assisted microdensitometry, and optical density values were subsequently converted to $\mathrm{fmol} / \mathrm{mg}$ tissue. Hill plots approached unity in all areas examined. The values reported are the means of at least 2 separate experiments on groups of 3 animals. 
Table 3. Regional distribution of ${ }^{3} \mathrm{H}-\mathrm{SCH} 23390$ binding sites (dopamine $\mathrm{D}-1$ receptors) in rat brain

\begin{tabular}{|c|c|c|}
\hline Area & $\begin{array}{l}{ }^{3} \mathrm{H}-\mathrm{SCH} 23390 \\
\text { bound (fmol/ } \\
\text { mg tissue } \pm \\
\text { SEM) }\end{array}$ & $\begin{array}{l}\text { Binding } \\
\text { relative } \\
\text { to the } \\
\text { caudate- } \\
\text { putamen } \\
(\%) \\
\end{array}$ \\
\hline \multicolumn{3}{|l|}{ Amygdala } \\
\hline Basolateral nucleus (BL) & $7.47 \pm 0.37$ & 8.7 \\
\hline Basolateral nucleus, ventral part (BLV) & $19.84 \pm 1.59$ & 23.1 \\
\hline Central nucleus (Ce) & $1.01 \pm 0.26$ & 1.2 \\
\hline Intercalated nucleus (I) & $33.70 \pm 1.88$ & 39.3 \\
\hline Lateral nucleus $(\mathrm{L})$ & $2.36 \pm 0.28$ & 2.8 \\
\hline Medial nucleus (Me) & $29.68 \pm 1.20$ & 34.6 \\
\hline Posteromedial cortical nucleus (PMCo) & $12.34 \pm 0.87$ & 14.4 \\
\hline \multicolumn{3}{|l|}{ Basal ganglia } \\
\hline Caudate putamen $(\mathrm{CPu})$ & $85.76 \pm 2.23$ & 100.0 \\
\hline Globus pallidus (GP) & $6.91 \pm 0.52$ & 8.1 \\
\hline Ventral pallidum (VP) & $19.48 \pm 0.89$ & 22.7 \\
\hline \multicolumn{3}{|l|}{ Brain stem and midbrain } \\
\hline Central gray (CG) & $1.24 \pm 0.11$ & 1.4 \\
\hline Dorsal raphe nucleus (DR) & $1.36 \pm 0.29$ & 1.6 \\
\hline Interpeduncular nucleus (IP) & $1.86 \pm 0.10$ & 2.2 \\
\hline Substantia nigra compacta (SNC) & $6.55 \pm 0.58$ & 7.6 \\
\hline Substantia nigra lateralis (SNL) & $1.94 \pm 0.20$ & 2.3 \\
\hline Substantia nigra reticulata (SNR) & $83.15 \pm 5.79$ & 97.0 \\
\hline $\begin{array}{l}\text { Superficial gray layer of the superior } \\
\text { colliculus }(\mathrm{SuG})\end{array}$ & $4.00 \pm 0.21$ & 4.7 \\
\hline \multicolumn{3}{|l|}{ Cortex } \\
\hline \multicolumn{3}{|l|}{ Anterior cingulate $(\mathrm{ACg})$} \\
\hline Laminae I-II & $2.22 \pm 0.27$ & 2.6 \\
\hline Laminae III-IV & $2.32 \pm 0.08$ & 2.7 \\
\hline Laminae V-VI & $6.45 \pm 0.46$ & 7.5 \\
\hline Entorhinal (Ent) & $8.11 \pm 0.31$ & 9.5 \\
\hline \multicolumn{3}{|l|}{ Frontal (Fr) } \\
\hline Anteromedial system (AM) & $6.27 \pm 0.22$ & 7.3 \\
\hline Lamina I & $1.24 \pm 0.13$ & 1.4 \\
\hline Laminae II-III & $1.02 \pm 0.14$ & 1.2 \\
\hline Lamina IV & $1.95 \pm 0.25$ & 2.3 \\
\hline Lamina V & $1.86 \pm 0.07$ & 2.2 \\
\hline Lamina VI & $2.23 \pm 0.25$ & 2.6 \\
\hline Suprarhinal system (SRH) & $4.85 \pm 0.21$ & 5.7 \\
\hline \multicolumn{3}{|l|}{ Frontoparietal (FrPa) } \\
\hline Lamina I & $0.49 \pm 0.04$ & 0.6 \\
\hline Laminae II-III & $0.81 \pm 0.06$ & 0.9 \\
\hline Lamina IV & $0.81 \pm 0.02$ & 0.9 \\
\hline Lamina V & $1.22 \pm 0.08$ & 1.4 \\
\hline Lamina VI & $1.09 \pm 0.09$ & 1.3 \\
\hline \multicolumn{3}{|l|}{ Posterior cingulate $(\mathrm{PCg})$} \\
\hline Laminae I-II & $1.34 \pm 0.17$ & 1.6 \\
\hline Laminae III-IV & $1.30 \pm 0.10$ & 1.5 \\
\hline Laminae V-VI & $1.35 \pm 0.15$ & 1.6 \\
\hline Primary olfactory $(\mathrm{Po})$ & $4.88 \pm 0.17$ & 5.7 \\
\hline Retrosplenial (RSpl) & $0.91 \pm 0.20$ & 1.1 \\
\hline
\end{tabular}

Table 3. Continued

\begin{tabular}{|c|c|c|}
\hline Area & $\begin{array}{l}{ }^{3} \mathrm{H}-\mathrm{SCH} 23390 \\
\text { bound (fmol/ } \\
\text { mg tissue } \pm \\
\text { SEM) }\end{array}$ & $\begin{array}{l}\text { Binding } \\
\text { relative } \\
\text { to the } \\
\text { caudate- } \\
\text { putamen } \\
(\%)\end{array}$ \\
\hline \multicolumn{3}{|l|}{ Striate (Str) } \\
\hline Lamina I & $0.63 \pm 0.10$ & 0.7 \\
\hline Laminae II-III & $0.61 \pm 0.10$ & 0.7 \\
\hline Lamina IV & $1.14 \pm 0.09$ & 1.3 \\
\hline Lamina $\mathrm{V}$ & $1.22 \pm 0.18$ & 1.4 \\
\hline Lamina VI & $4.10 \pm 0.28$ & 4.8 \\
\hline \multicolumn{3}{|l|}{ Temporal (Te) } \\
\hline Lamina I & $2.70 \pm 0.32$ & 3.1 \\
\hline Laminae II-III & $2.45 \pm 0.37$ & 2.9 \\
\hline Lamina IV & $2.30 \pm 0.26$ & 2.7 \\
\hline Lamina V & $2.44 \pm 0.52$ & 2.8 \\
\hline Lamina VI & $4.17 \pm 0.40$ & 4.9 \\
\hline \multicolumn{3}{|l|}{ Hippocampus } \\
\hline Dentate gyrus, molecular layer (Mol) & $2.72 \pm 0.19$ & 3.2 \\
\hline \multicolumn{3}{|l|}{ Field CA1 of Ammon's horn (CA1) } \\
\hline Lacunosum molecular layer (LMO1) & $0.56 \pm 0.04$ & 0.7 \\
\hline Oriens layer (Or) & $0.82 \pm 0.09$ & 1.0 \\
\hline Field CA2 of Ammon's horn (CA2) & $0.65 \pm 0.09$ & 0.8 \\
\hline Field CA3 of Ammon's horn (CA3) & $0.96 \pm 0.04$ & 1.1 \\
\hline Field CA4 of Ammon's horn (CA4) & $1.69 \pm 0.23$ & 2.0 \\
\hline Subiculum (S) & $1.52 \pm 0.08$ & 1.8 \\
\hline \multicolumn{3}{|l|}{ Hypothalamus } \\
\hline Anterior hypothalamic area (AHy) & $0.62 \pm 0.06$ & 0.7 \\
\hline Arcuate nucleus (Arc) & $0.48 \pm 0.06$ & 0.6 \\
\hline Posterior nucleus (Pn) & $1.28 \pm 0.08$ & 1.5 \\
\hline Suprachiasmatic nucleus (SCh) & $12.02 \pm 0.27$ & 14.0 \\
\hline Ventromedial nucleus (VMH) & $0.89 \pm 0.30$ & 1.0 \\
\hline \multicolumn{3}{|l|}{ Septal area } \\
\hline Accumbens nucleus (Acb) & $64.20 \pm 3.24$ & 74.9 \\
\hline \multicolumn{3}{|c|}{ Lateral septal nucleus, intermediate part } \\
\hline$(\mathrm{LSI})$ & $2.53 \pm 0.17$ & 3.0 \\
\hline \multicolumn{3}{|l|}{ Lateral septal nucleus, dorsal part } \\
\hline (LSD) & $8.31 \pm 0.42$ & 9.7 \\
\hline Medial septal nucleus (MS) & $1.21 \pm 0.25$ & 1.4 \\
\hline \multicolumn{3}{|l|}{ Thalamus } \\
\hline Anterodorsal nucleus (AD) & $2.00 \pm 0.11$ & 2.3 \\
\hline Anteromedial nucleus (Am) & $2.34 \pm 0.09$ & 2.7 \\
\hline Anteroventral nucleus (AV) & $4.56 \pm 0.05$ & 5.3 \\
\hline Dorsolateral geniculate nucleus (DLG) & $3.02 \pm 0.29$ & 3.5 \\
\hline Lateral habenular nucleus (LHb) & $0.30 \pm 0.01$ & 0.3 \\
\hline Laterodorsal nucleus (LD) & $1.52 \pm 0.02$ & 1.8 \\
\hline Medial geniculate nucleus (MG) & $0.39 \pm 0.03$ & 0.5 \\
\hline Medial habenular nucleus (MHb) & $0.15 \pm 0.03$ & 0.2 \\
\hline Mediodorsal nucleus (MD) & $1.11 \pm 0.20$ & 1.3 \\
\hline Paraventricular nucleus (PV) & $3.27 \pm 0.16$ & 3.8 \\
\hline Reticular nucleus (Rt) & $0.35 \pm 0.10$ & 0.4 \\
\hline Ventrolateral nucleus (VL) & $0.92 \pm 0.02$ & 1.1 \\
\hline Ventrolateral geniculate nucleus (VLG) & $1.11 \pm 0.08$ & 1.3 \\
\hline Ventromedial nucleus (VM) & $3.11 \pm 0.07$ & 3.6 \\
\hline
\end{tabular}


Table 3. Continued

\begin{tabular}{lrr} 
& & $\begin{array}{l}\text { Binding } \\
\text { relative } \\
\text { to the }\end{array}$ \\
& $\begin{array}{l}{ }^{3} \mathrm{H}-\mathrm{SCH} 23390 \\
\text { bound (fmol/ } \\
\text { mg tissue } \pm \\
\text { caudate- } \\
\text { putamen } \\
\text { (\%) }\end{array}$ \\
\hline Area & & \\
\hline Remaining forebrain areas & $6.89 \pm 0.67$ & 8.0 \\
Anterior olfactory nuclei (AON) & $15.28 \pm 0.92$ & 17.8 \\
Claustrum (Cl) & $10.42 \pm 0.92$ & 12.2 \\
Endopiriform nucleus (En) & $27.89 \pm 1.96$ & 32.5 \\
Entopeduncular nucleus (EP) & $2.14 \pm 0.15$ & 2.5 \\
Islands of Calleja (ICj) & $32.61 \pm 1.44$ & 38.0 \\
Islands of Calleja, major island (ICjM) & $4.51 \pm 0.33$ & 5.3 \\
Lateral ventricle (LV) & $78.81 \pm 3.52$ & 91.9 \\
Olfactory tubercle (Tu) & $12.80 \pm 0.67$ & 14.9 \\
Subthalamic nucleus (STh) & $1.73 \pm 0.27$ & 2.0 \\
Ventral tegmental area (VTA) & & \\
Zona incerta (ZI) & $1.48 \pm 0.20$ & 1.7 \\
$\quad$ Medial & $6.94 \pm 1.12$ & 8.1 \\
$\quad$ Lateral & &
\end{tabular}

Slide-mounted brain sections were labeled as described in the text with $1 \mathrm{~nm}^{3} \mathrm{H}$ SCH 23390 and apposed to LKB Ultrofilm for 21 or $42 \mathrm{~d}$ to generate autoradiograms. Nonspecific binding was defined by labeling in the presence of $5 \times 10^{-6} \mathrm{M}$ fluphenazine and was subtracted from all readings. The data were analyzed and quantitated as described in the text and the legend to Table 1 . The values reported represent means \pm SEM of 3 experiments ( 3 animals). Furthermore, the amount of binding (expressed as a percentage) relative to the most enriched area, the caudate-putamen, is reported. At least 5 densitometric readings were taken from each brain structure. high levels of receptors. The medial nucleus demonstrated a variation in receptor density, the most rostral aspects contained moderate concentrations, the caudal aspects contained low amounts, and the nucleus at the level of the dorsal hypothalamic area exhibited high concentrations (not shown). A small area on the lateral inferior aspect of the lateral nucleus (Fig. $5 B$ ) contained high concentrations of autoradiographic grains, whereas the rest of the lateral nucleus had very low numbers. The basolateral nucleus had a uniform distribution of a low amount of autoradiographic grains, whereas the central, basomedial, and anterior cortical nuclei contained very low amounts. In addition, the posteromedial cortical nucleus contained a moderate amount of D-1 receptors.

\section{Hippocampus}

There were very few ${ }^{3} \mathrm{H}-\mathrm{SCH} 23390$ binding sites in the hippocampal formation. However, there was a laminar distribution, in that the molecular layer of the dentate gyrus contained approximately 5 times as many receptors as the other areas (Fig. $4, B, C)$.

\section{Hypothalamus}

The suprachiasmatic nucleus exhibited a moderate concentration of D-1 receptors, whereas the other areas and nuclei of the hypothalamus contained very low numbers of D-1 receptors (Figs. 4, $A-C ; 5 A$ ).

\section{Thalamus}

Very low D-1 receptor densities were observed in all thalamic nuclei. The anterodorsal, anteromedial, anteroventral, dorsolateral geniculate, paraventricular, and ventromedial nuclei contained the highest concentration of D-1 receptors (Figs. 4, A$C ; 5, A, B)$.

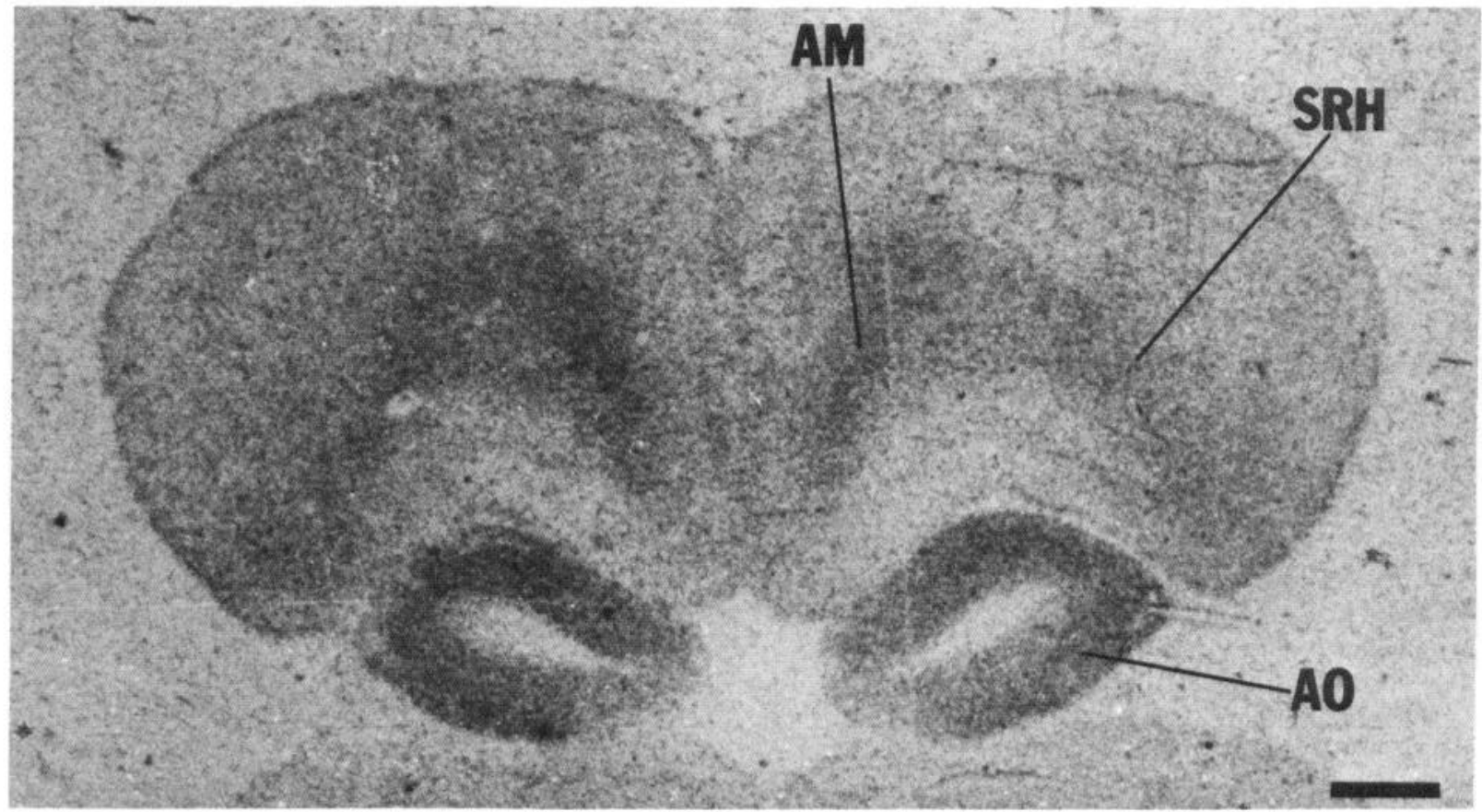

Figure 2. Localization of D-1 receptors in rat prefrontal cortex. Bright-field photomicrograph of a representative autoradiogram through a section of rat prefrontal cortex. As discussed in the text, slide-mounted tissue sections were labeled with $1 \mathrm{nM}^{3} \mathrm{H}-\mathrm{SCH} 23390$. Autoradiograms were generated by apposition of labeled tissue sections to tritium-sensitive film for 6 weeks. Low concentrations of D-1 receptors are seen in the anteromedial $(A M)$ and suprarhinal $(S R H)$ systems of the prefrontal cortex. In addition, low concentrations of D-1 receptors are observed in the anterior olfactory nuclei $(A O)$. Bar, $1 \mathrm{~mm}$. 
Figure 3. Specific ${ }^{3} \mathrm{H}-\mathrm{SCH} .23390$ binding to rat brain sections. $A$, Photomicrograph from an autoradiogram generated by apposition of labeled tissue sections (incubated with $1 \mathrm{nM}{ }^{3} \mathrm{H}$ SCH 23390) to tritium-sensitive film for 3 weeks. Autoradiographic grains appear on LKB Ultrofilm as black dots against a white background. Note the very high concentration of D-1 receptors in the caudate-putamen $(C P u)$, accumbens nucleus $(A c b)$, and olfactory tubercle $(T u)$. Abbreviations: $\mathrm{ACg}$, anterior cingulate cortex; $\mathrm{FrPa}$, frontoparietal cortex, $\mathrm{Cl}$, claustrum, $E n$, endopiriform nucleus, $L S$, lateral septal nuclei. Abbreviations and structures are identified according to Paxinos and Watson (1982). B, Autoradiogram in this photomicrograph is from a section adjacent to the one shown in $A$, incubated with added $5 \times$ $10^{-6} \mathrm{M}$ fluphenazine. The low density of autoradiographic grains observed demonstrates that the majority of grains appearing in $A$ are due to specific ${ }^{3} \mathrm{H}-\mathrm{SCH} 23390$ binding. Bar, 500 $\mu \mathrm{m}$.

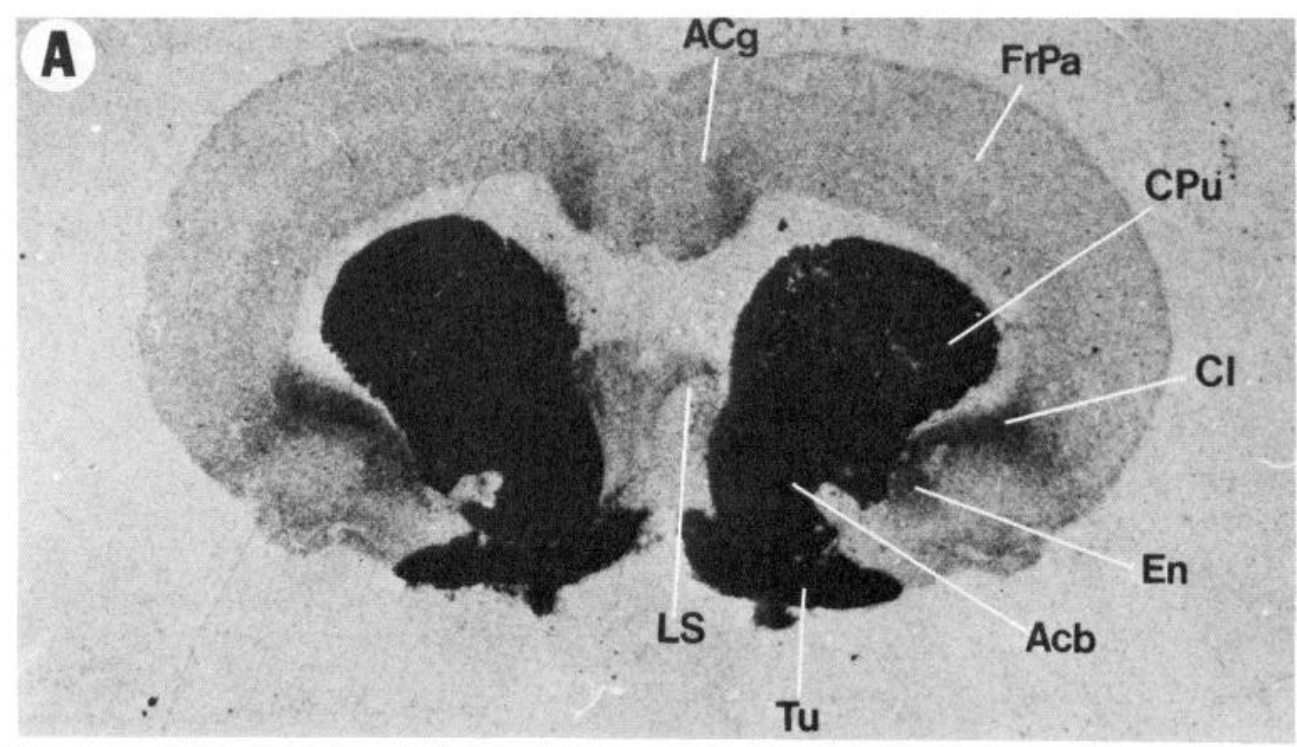

B

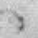



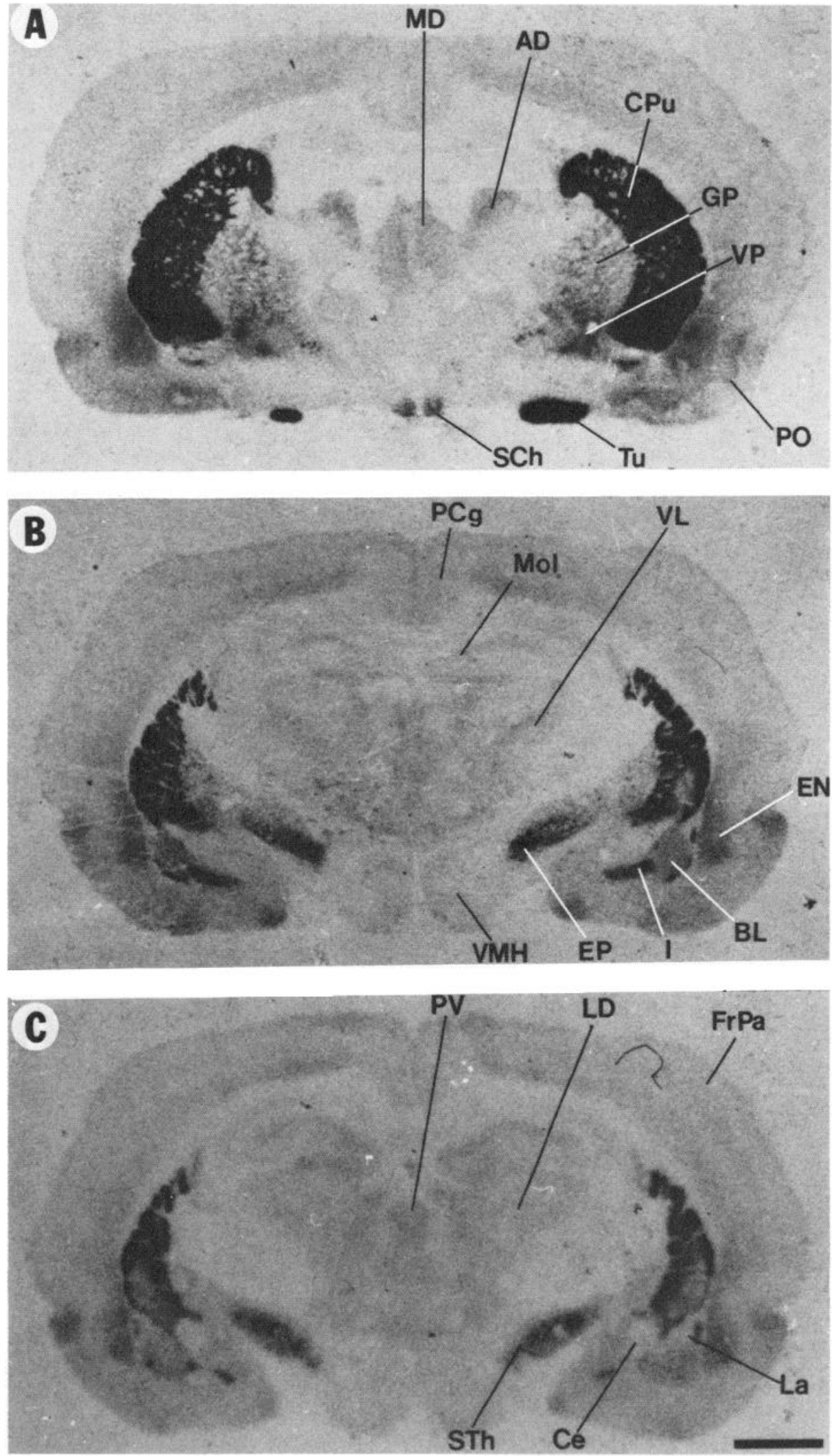

Figure 4. $A-C$, Regional distribution of D-1 receptors in rat forebrain sections. Photomicrographs from autoradiograms generated by apposition to tritium-sensitive film for 3 weeks. Anatomical localization of D-1 receptors were confirmed by staining the labeled tissue sections and comparing them to autoradiograms using the atlas of Paxinos and Watson (1982).

Nonspecific binding, determined in the presence of $5 \times 10^{-6} \mathrm{M}$ fluphenazine, produced uniform grain densities slightly above background levels. Abbreviations as in Table 3. Bar, 500 $\mu \mathrm{m}$. 

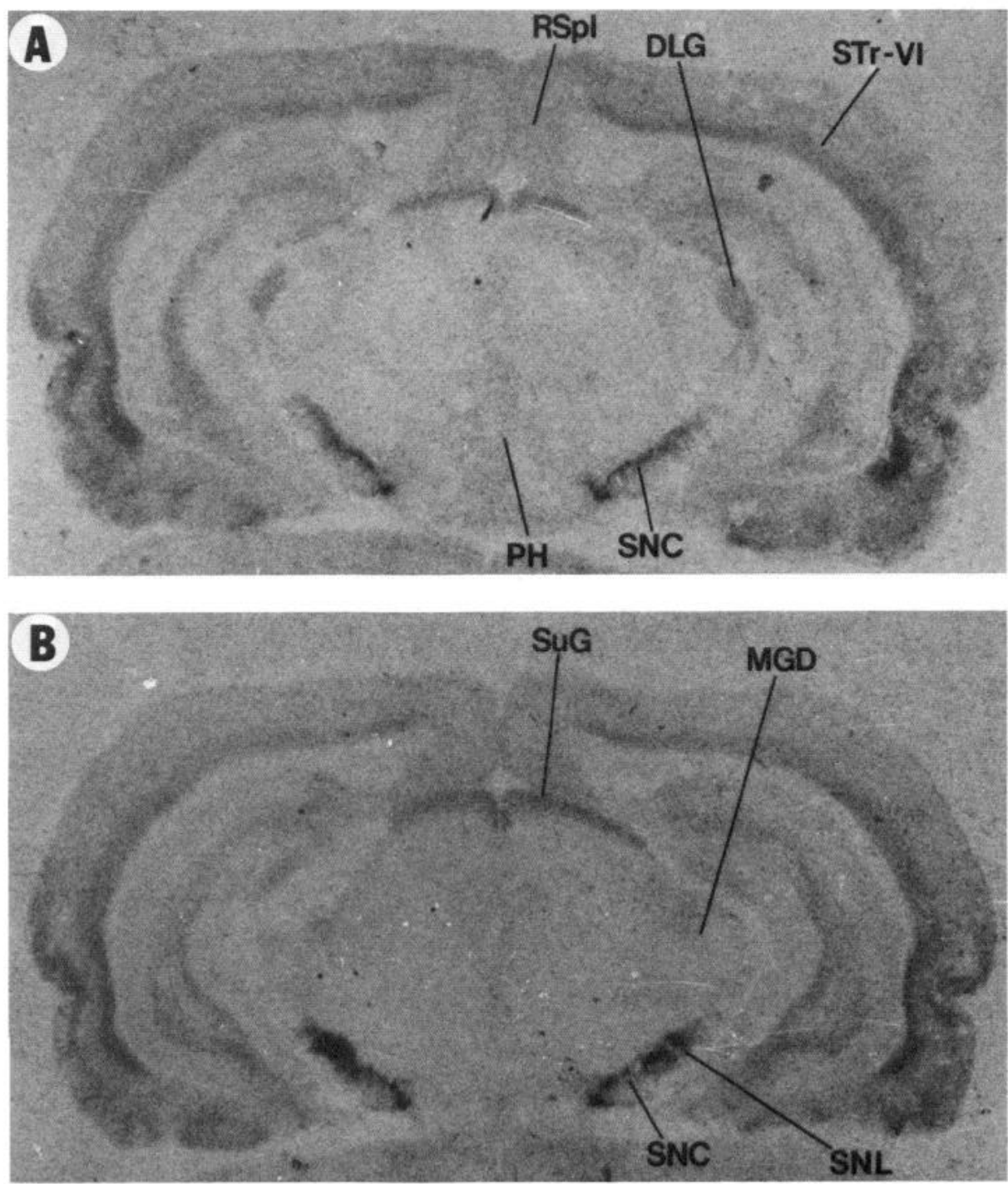

Figure 5. $A-C$, Regional distribution of D-1 receptors in sections of rat forebrain in a rostral-caudal gradient through the substantia nigra. Abbreviations as in Table 3. Bar, $500 \mu \mathrm{m}$.

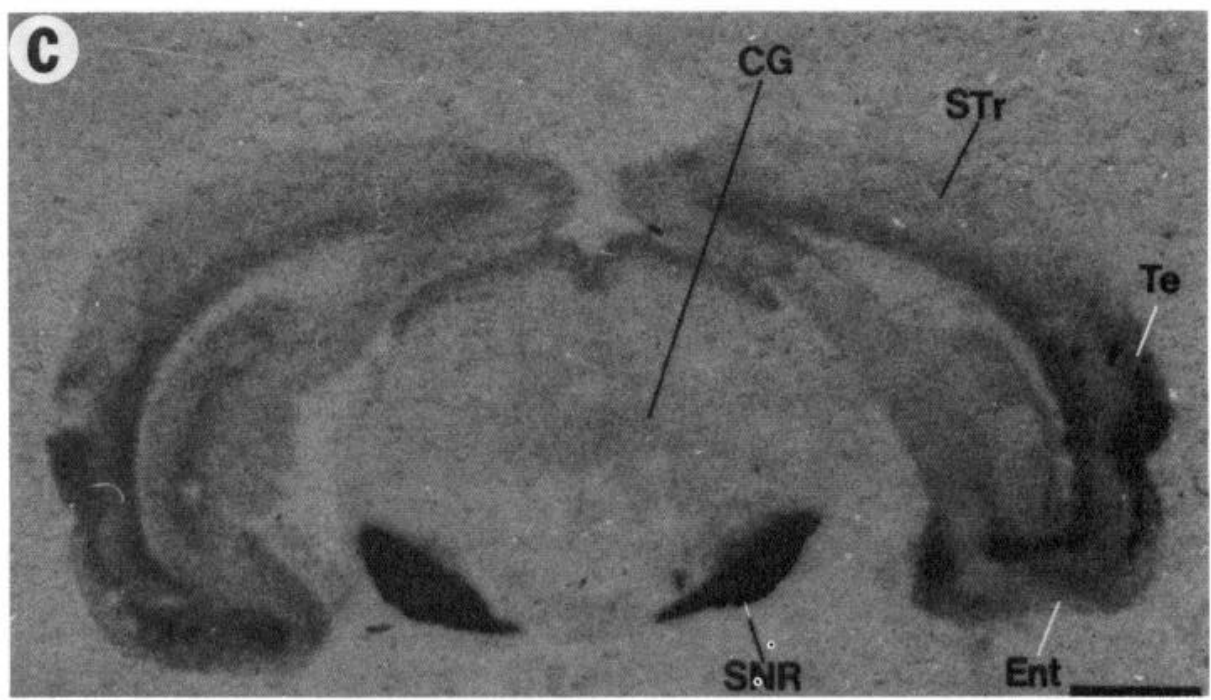


of very low amounts of ${ }^{3} \mathrm{H}-\mathrm{SCH} 23390$ binding sites (data not shown).

\section{Discussion}

${ }^{3} \mathrm{H}-\mathrm{SCH} 23390$ labels DA receptors of the D-1 type (Billard et al., 1984; Dawson et al., 1985a; Schulz et al., 1985). The similar high affinity and saturable binding of ${ }^{3} \mathrm{H}-\mathrm{SCH} 23390$ to slidemounted tissue sections, coupled with the potency and stereoselectivity of piflutixol isomers, indicated that the binding under the conditions employed for autoradiography involves the same sites as those seen in homogenate studies. It was possible to analyze the pharmacologic characteristics and specificity of ${ }^{3} \mathrm{H}$ SCH 23390 binding to several microscopic regions of the brain by combining quantitative autoradiography with classic saturation and competition experiments (utilizing ${ }^{3} \mathrm{H}-\mathrm{SCH} 23390$ to label the D-1 receptor). The $K_{\mathrm{i}}$ values reported by Billard et al. (1984), utilizing ${ }^{3} \mathrm{H}-\mathrm{SCH} 23390$ to label the D-1 receptors, and the $K_{\mathrm{i}}$ values reported by Leff et al. (1985) for ${ }^{3} \mathrm{H}$-flupenthixol binding to $\mathrm{D}-1$ receptors using striatal membrane preparations, are in close agreement with those we have obtained for several brain structures by quantitative autoradiography. A comparison between the $K_{\mathrm{i}}$ values obtained in the present autoradiographic study with those obtained in membrane homogenates in an area corresponding to the caudate-putamen can be found in Table 4 . In addition, Scatchard analysis of the saturation isotherms yielded $K_{\mathrm{d}}$ and $B_{\max }$ values approximately equal to those reported in brain homogenate studies (Billard et al., 1984; Schulz et al., 1985). Therefore, the results presented here provide the first detailed quantitative analysis of the distribution of $\mathrm{D}-1$ receptors in the rat brain.

Physiological studies have indicated that SCH 23390 interacts potently with the 5-HT neuronal system. For example, in vitro studies indicate that SCH 23390 competes with 5-HT-induced constriction of isolated perfused artery preparations (Hicks et al., 1984; Ohlstein and Berkowitz, 1985), a 5-HT 2 receptormediated phenomenon, with nanomolar potency. SCH 23390 also inhibits $5-\mathrm{HT}_{2}$-sensitive ${ }^{3} \mathrm{H}$-spiperone binding with nanomolar affinity (Christensen et al., 1984; Hicks et al., 1984; Hyttel, 1983) and $5-\mathrm{HT}_{1}$-sensitive ${ }^{3} \mathrm{H}-5-\mathrm{HT}$ binding with micromolar affinity (Hicks et al., 1984). It is well known that spiperone is not a selective $5-\mathrm{HT}_{2}$ ligand, in that it interacts with the dopaminergic and adrenergic systems and it labels a spirodecanone site with high potency (Leysen et al., 1981; Morgan et al., 1984; Palacios et al., 1981a). Therefore, competition experiments performed with spiperone should be interpreted with caution. When using the more selective $5-\mathrm{HT}_{2}$ ligand, ketanserin (Laduron et al., 1982; Leysen et al., 1981, 1982) in competition experiments with ${ }^{3} \mathrm{H}-\mathrm{SCH} 23390$ binding, a $K_{\mathrm{i}}$ of 1005 nM was obtained in striatal membrane preparations (Billard et al., 1984). This is in close agreement with our results, obtained in several microscopic brain regions by quantitative autoradiography (Tables 1,4$)$, and thus possibly indicates a moderate interaction of ${ }^{3} \mathrm{H}-\mathrm{SCH} 23390$ with $5-\mathrm{HT}_{2}$ receptors. However, competition experiments utilizing ketanserin to displace $5-\mathrm{HT}_{2}$ receptor binding should also be interpreted with caution. Ketanserin labels $5-\mathrm{HT}_{2}$ receptors in certain discrete regions of the brain (such as the claustrum, endopiriform nucleus, and lamina IV of the neocortex), whereas in the basal ganglia and several other rat brain structures, including the dorsal raphe, ${ }^{3} \mathrm{H}$-ketanserin binding is predominantly due to an interaction with the ketanserinrecognition binding site (Leysen et al., 1983; Pazos et al., 1985). Methysergide, another 5-HT antagonist utilized in these studies, has a complex pharmacological picture in that it interacts not only with $5-\mathrm{HT}_{2}$ receptors (Leysen et al., 1982), but also with dopaminergic and adrenergic receptors. Despite the inadequacies of ketanserin and methysergide as $5-\mathrm{HT}_{2}$ ligands, there is at least a 100 -fold greater selectivity for the D-1 receptor versus
Table 4. Comparison of the D-1 receptor affinities $\left(K_{i}\right)$ of several drugs as determined by quantitative autoradiography with ${ }^{3} \mathrm{H}-\mathrm{SCH}$ 23390 and by binding assay in striatal membrane preparations labeled with ${ }^{3} \mathrm{H}$-flupentixol or ${ }^{3} \mathrm{H}-\mathrm{SCH} 23390$

\begin{tabular}{lccc} 
Drug & $\begin{array}{c}\text { Quantitative } \\
\text { autoradiography }\end{array}$ & $\begin{array}{l}{ }^{3} \mathrm{H}-\mathrm{SCH} \\
\text { binding }^{a}\end{array}$ & $\begin{array}{l}{ }^{3} \mathrm{H} \text {-Flupentixol } \\
\text { binding }^{b}\end{array}$ \\
\hline Fluphenazine & 11.2 & 11.2 & 2.7 \\
cis-(Z)-Piflutixol & 1.09 & 2.9 & 0.4 \\
trans-(E)-Piflutixol & 1210 & 95 & 254 \\
Sulpiride (S) & 50,000 & 100,000 & $1,051,000$ \\
SCH 23390 & 0.343 & 0.3 & 0.28 \\
SKF 38393 & 56.8 & - & $3.1\left(K_{\mathrm{h}}\right)$ \\
& & 1005 & $158\left(K_{1}\right)$ \\
Ketanserin & 541 & 217 & - \\
Methysergide & 362 & - & - \\
Atropine & $c$ & 100,000 & - \\
Diazepam & $c$ & - & - \\
Forskolin & $c$ & - & - \\
Naloxone & $c$ & - & 0 \\
Nomifensine & $c$ & - & 10,000 \\
Propranolol & $c$ & 44,000 & - \\
Serotonin (5-HT) & $c$ & - & - \\
Triprolidine & $c$ & & \\
\hline
\end{tabular}

a Taken from Billard et al. (1984).

${ }^{b}$ Taken from Leff et al. (1985).

' A $10 \mu \mathrm{M}$ concentration failed to displace ${ }^{3} \mathrm{H}-\mathrm{SCH} 23390$ from slide-mounted lissue sections as determined by quantitative autoradiography.

$K_{\mathrm{h}}$ and $K_{1}$ are high- and low-affinity $K_{\mathrm{i}}$ 's, respectively, for ${ }^{3} \mathrm{H}$-flupentixol binding competition studies with SKF 38393 (Leff et al., 1985).

the $5-\mathrm{HT}_{2}$ receptor as defined by ${ }^{3} \mathrm{H}-\mathrm{SCH} 23390$ binding to slide-mounted tissue sections. One can speculate that there may even be a greater selectivity given the complex pharmacology of ketanserin and methysergide. Support for this hypothesis can be found when comparing the anatomical distribution and density of $5-\mathrm{HT}_{2}$ and $\mathrm{D}-1$ receptors, since there is a marked andtomical difference in the location of these receptors (Pazos et al., 1985). However, in structures containing a moderate to high $5-\mathrm{HT}_{2}$ receptor density (such as lamina IV of the neocortex, claustrum, endopiriform nucleus, and suprachiasmatic nucleus), there could possibly be a minimal to moderate interaction of ${ }^{3} \mathrm{H}-\mathrm{SCH} 23390$ binding with $5-\mathrm{HT}_{2}$ receptors. The results presented and discussed in this communication also suggest that under the conditions we employed to label dopamine D-1 receptors with ${ }^{3} \mathrm{H}-\mathrm{SCH} 23390$, there is a nonsignificant labeling of $5-\mathrm{HT}_{1}$ receptors. Serotonin inhibited ${ }^{3} \mathrm{H}-\mathrm{SCH} 23390$ binding with a $K_{\mathrm{i}}$ of $44,000 \mathrm{nM}$ in striatal membrane preparations (Billard et al., 1984), and a $10 \mu \mathrm{M}$ concentration of 5-HT failed to inhibit ${ }^{3} \mathrm{H}-\mathrm{SCH} 23390$ binding as determined by quantitative autoradiography.

SCH 23390 has been reported to be very potent in blocking psychopharmacological effects that are generally believed to be characteristic of D-2 receptor antagonists (Creese et al., 1983), such as amphetamine-induced locomotor behavior and certain apomorphine-induced stereotypies (Christensen et al., 1984; Iorio et al., 1983; Mailman et al., 1984). In vitro studies involving the inhibition of the potassium-evoked release of radiolabeled $\mathrm{ACh}$, a functional model system for the D-2 receptor (Stoof and Kebabian, 1982), have demonstrated that SCH 23390 dose dependently inhibited this phenomenon (Plantje et al., 1984a, b). However, Plantje et al. (1984b) pointed out that SCH 23390 has 10,000 -fold greater selectivity for D-1 versus D-2 receptors 
in their functional D-1 and D-2 receptor assay. SCH 23390 had a 100,000 -fold selectivity for D-1 over D-2 receptors, as determined by comparing the $\mathrm{IC}_{50}$ values for the inhibition of $\mathrm{DA}$ stimulated adenylate cyclase activity and ${ }^{3} \mathrm{H}$-spiroperidol binding, respectively (Iorio et al., 1983). Under our conditions, the selective D-2 antagonist sulpiride inhibited ${ }^{3} \mathrm{H}-\mathrm{SCH} 23390$ binding with a $K_{\mathrm{i}}$ of greater than $10,000 \mathrm{~nm}$ (Table 1), indicating that ${ }^{3} \mathrm{H}-\mathrm{SCH} 23390$ binding is highly selective for the D-1 receptor. When comparing the anatomical distribution of D-2 receptors, as determined by autoradiography (Gehlert and Wamsley, 1984, 1985; Gehlert et al., 1986; Klemm et al., 1979; Martres et al., 1985a, b; Murrin et al., 1979; Palacios and Wamsley, 1984; Palacios et al., 1981a; Sokoloff et al., 1985), with that of the D-1 receptor, a marked regional difference in the anatomic location of the 2 dopamine subtypes is noted, further demonstrating the selectivity of SCH 23390 for the D-1 receptor. In addition to the regional differences, there are areas of significant overlap, suggesting a possible modulatory role between the 2 DA receptor systems.

Recently, Leff et al. (1985) combined computer-modeling techniques with classic competition experiments to investigate the interaction of dopaminergic agonists and antagonists with ${ }^{3} \mathrm{H}$-antagonist-labeled D-1 receptors. They were able to show that antagonist $/{ }^{3} \mathrm{H}$-antagonist competition curves model a single $\mathrm{D}-1$ receptor, whereas agonist $/{ }^{3} \mathrm{H}$-antagonist competition curves best model a high- and low-affinity agonist binding of the D-1 receptor. Preliminary observations reported in the present study (Table 1) concerning the selective D-1 agonist SKF 38393 used in competition with the binding of ${ }^{3} \mathrm{H}-\mathrm{SCH} 23390$ indicate that the resulting competition curve is extremely shallow for certain brain areas and that the binding is subject to guanine nucleotide regulation (data not shown). This suggests the presence of heterogeneous populations of agonist-binding states of the D-1 receptor. These sites may be differentially localized by using the quantitative technique of receptor autoradiography, as has been accomplished with the high- and low-affinity states of the D-2 receptor (Dawson et al., 1985b).

Cortical DA innervation was initially discovered by combining biochemical and lesion studies (Thierry et al., 1973a, b). Further biochemical and histochemical investigations combined with selective lesioning experiments demonstrated that DA, DA-containing fibers, and DA-containing nerve terminals are present in the deep layers of the frontal, cingulate, and entorhinal cortices (Berger et al., 1974; Lindvall and Bjorklund, 1974; Lindvall et al., 1974; Tassin et al., 1974, 1975). In addition, DA-sensitive adenylate cyclase activity was identified in the cerebral cortex (Von Hungen and Roberts, 1973), suggesting the existence of DA receptors; this was later confirmed by other investigators (Bockaert et al., 1977; Mishra ct al., 1975). An extension of knowledge and a possible verification of the functional role of these DA terminals would involve the localization of DA receptors in the cerebral cortex. Murrin and Kuhar (1979) localized DA receptors in vivo using ${ }^{3} \mathrm{H}$-spiperone, a D-2 antagonist, to the anterior cingulate cortex and the suprarhinal and supra-accumbal areas at the level of the forceps minor. In vitro studies using ${ }^{3} \mathrm{H}$-spiperone (Palacios and Wamsley, 1984; Palacios et al., 1981 a), ${ }^{3} \mathrm{H}$-sulpiride (Gehlert and Wamsley, 1985), ${ }^{3} \mathrm{H}-(-)-D 0710$ (Sokoloff et al., 1985), and ${ }^{125}$ I-iodosulpride (Martrcs ct al., 1985a, b) confirmed the existence of D-2 receptors in the cortices. The results presented here also demonstrate the existence of D-1 receptors in the prefrontal cortex and show that their distribution (Fig. 2) closely parallels the distribution of DA nerve terminals determined by Berger et al. (1976), Lindvall and Bjorklund (1984), and Thierry et al. (1984).

Von Hungen and Roberts (1973) demonstrated the existence of a DA-sensitive adenylate cyclase, a property consistent with the presence of D-1 receptors (Kebabian and Calne, 1979), in the cerebral cortex. Later, an excellent correlation was observed between the topographical distribution of DA-sensitive adenylate cyclase activity and DA levels in various cortical areas (Bockaret et al., 1977; Tassin et al., 1978; Thierry et al., 1984). The results presented here support these observations, since the distribution of the $\mathrm{D}-1$ receptors tends to parallel closely that of DA-sensitive adenylate cyclase. Bilateral electrolytic lesions of ventral mesencephalic tegmentum produce an increase in the DA-sensitive adenylate cyclase activity, indicating a postsynaptic localization for cortical D-1 receptors (Tassin et al., 1982). Of interest would be the confirmation of this finding by combining the technique of autoradiography with selective lesioning experiments.

DA innervation of the cerebral cortex has been extensively studied in the rat. The DA fibers are distributed in layers IIVI, with highest density in layers V and VI (for review, see Lindvall and Bjorklund, 1983, 1984). This same general trend was observed for D-1 receptors, with the deeper layers containing higher densities of receptors than the superficial layers. In contrast, the laminar distribution of the D-2 receptor (Martres et al., 1985b) is unique and different from that of the D-1 receptor: D-2 receptors are mainly localized to lamina $V$, with very small concentrations in laminae I-III and VI. DA terminals, with relatively well-defined projections, have been observed in the cortices of rat brain, except for the striate cortex (Lindvall and Bjorklund, 1983). However, evidence has been obtained for a DA projection from the A10 region to the visual cortex in the cat (Tork and Turner, 1981).

The localization of D-1 receptors described here in other brain structures also correlates well with the distribution of dopaminergic nerve terminals. Areas containing high concentrations of $\mathrm{D}-1$ receptors in general have been reported to contain nerve endings from dopaminergic neurons, primarily those located in the substantia nigra, ventral tegmental area, and retrorubral nucleus (see Lindvall and Bjorklund, 1983, 1984, for review). The basal ganglia, septal nuclei, the different nuclei of the amygdaloid complex, hippocampus, subthalamic nucleus, claustrum, and entopeduncular nucleus are structures where the presence of DA, DA fibers, and DA biochemical markers has been observed (for review and references, see Lindvall and Bjorklund, 1983, 1984; Moore and Bloom, 1978). The results presented here suggest that besides being associated with nigrostriatal system, D-1 receptors are predominantly linked to the mesocortical system (see above), the mesodiencephalic system, and the incertohypothalamic system. In general, areas containing high concentrations of DA, DA fibers, or DA biochemical markers contain high concentrations of D-1 receptors. However, exceptions also occur, since a close correlation between the distribution of the receptors and the distribution of DA fibers or other markers does not exist in arcas such as the central amygdaloid nucleus (Ben-Ari et al., 1975; Fallon et al., 1978; Fuxe et al., 1974), the lateral habenular nucleus (Lindvall and Stenevi, 1978), or the medial caudal aspect of the zona incerta (Bjorklund et al., 1975). The existence of discrepancies between the location of receptors and the distribution of fibers and neurotransmitters has been referred to as the "mismatch" problem (Kuhar, 1985a). The "mismatch" problem has also been found with the serotonergic system (Pazos and Palacios, 1985; Pazos et al., 1985) and the histaminergic system (Palacios et al., 1981b). Several explanations for these discrepancies have been proposed by $\mathrm{Ku}$ har (1985a), e.g., the receptors and neurotransmitters are contained within 2 completely different neurons, receptor ligands often label only a subpopulation of receptors, or autoradiographic efficiency due to gray and white matter quenching may lead to artifactual regional differences in receptor localization. Also, one must keep in mind that the brain contains D-2 receptors whose distribution differs from that of D-1 receptors, and this may account for several areas where DA markers exist but the $D-1$ receptor does not. 
White matter regions contained very low levels of ${ }^{3} \mathrm{H}-\mathrm{SCH}$ 23390 binding. However, we may have underestimated binding to those structures with high white matter content, in that white matter has a greater self-absorption (attenuation) of beta particles than gray matter (Alexander et al., 1981). In any case, in areas of predominantly white matter, this underestimation would be at most $30 \%$ (Rainbow et al., 1984), thus making the values reported for these areas actually semiquantitative as opposed to quantitative.

The D-1 receptor has been described as a "receptor in search of a function," or more appropriately as having "no known function" (Stoof and Kebabian, 1984). However, with the development of selective antagonists and agonists for both the D-1 and D-2 receptors, the individual roles these receptor subtypes play in CNS physiology are beginning to be elucidated. For example, until recently a behavioral role for the D-1 receptor has received little attention. In fact, on the basis of direct and indirect evidence, stereotypy has been considered to be a D-2 receptor-mediated process (Seeman, 1980). However, Molloy and Waddington (1985) have provided evidence that sniffing and grooming appear to be selectively mediated through D-1 mechanisms, and D-2 mechanisms seem to modulate the expression of rearing and locomotion initiated by D-1 stimulation. Furthermore, Iorio et al. (1983) have shown that SCH 23390 prevents the motor stimulation and arousal produced by apomorphine and amphetamine, and Gessa et al. (1985) demonstrated that when SCH 23390 prevents the excitatory response to apomorphine, the existence of a population of D-2 receptors mediating sedation and sleep is disclosed. These investigations suggest that a complex interaction occurs between D-1 and D-2 receptor occupancy. The blockade of one receptor type may produce an allosteric change in the other (Gessa et al., 1985), or possible interactions between these receptors may involve a change in adenylate cyclase activity. This could lead to a modulated physiological response depending on whether the D-1 or D-2 receptor was predominantly stimulated. It also appears that each receptor subtype has distinct and separate physiological functions, although the specific effects mediated by these receptors are still being elucidated.

A separate DA retinal system is known to exist (Moore and Bloom, 1978; Lindvall and Bjorklund, 1983). Results presented here suggest a central role for D-1 receptors in control of visual activity. The suprachiasmatic nucleus, which contains moderate concentrations of D-1 receptors, receives dircet retinal projections (Moore and Lenn, 1972) and is involved in circadian rhythms (Kupfermann, 1981). The superficial gray layer of the superior colliculus (Wurtz and Albano, 1980), the claustrum (LeVay and Sherk, 1981; Sanides and Buchholtz, 1979), the lateral geniculate nucleus, and the striate cortex (Gilbert and Wiesel, 1979; Toga and Collins, 1981) are all connected with the visual system and contain low concentrations of D-1 receptors.

Several neurological and psychiatric disorders such as tardive dyskinesia, Parkinson's disease, Huntington's chorea, Gilles de la Tourette's syndrome, schizophrenia, and drug-induced psychosis are involved with a disturbance of central dopaminergic systems. These observations imply that DA plays a very important role in cognitive function and integration of movement. Different areas of the cortex serve specific processing roles (see Iversen, 1983, 1984, for review) - the sensory cortex for modality-specific sensory analysis, the temporal lobe association cortex for perceptual analysis of complex sensory stimuli, and the frontal lobes serving the highest levels of neural integration. Results presented in this study indicate the existence of D-1 receptors in the cerebral cortices. This suggests that the D-1 receptor may play a direct role in cognitive function. We have recently used ${ }^{3} \mathrm{H}-\mathrm{SCH} 23390$ to label D-1 receptors in human cortex, and we found a low density of D-1 receptors in the superior frontal gyrus (unpublished observations). These results have interesting implications in the therapy of schizophrenia, which has been attributed to overactivity of cerebral dopaminergic mechanisms in the brain (see Rupniak et al., 1983, for review). Current antipsychotics in clinical use are, in general, potent D-2 antagonists, and long-term use is associated with the development of tardive dyskinesia, an irreversible involuntary movement disorder (for review, see DeVeaugh-Geiss, 1982). With the introduction of more selective agents for the dopamine receptor subtypes, perhaps therapy can be directed at the specific receptor alterations and reduce the severe adverse side effects in this and other disorders involving central dopaminergic systems.

Quantitative autoradiography of ${ }^{3} \mathrm{H}-\mathrm{SCH} 23390$ binding to rat brain sections provides a sensitive assay for the localization of D-1 receptors in well-defined highly circumscribed areas. The results of the present study demonstrate a striking correlation between D-1 receptors and terminals of dopaminergic pathways. The localization of D-1 receptors to several discrete brain structures will, we hope, help elucidate more of the physiologic functions associated with the D-1 receptor and ultimately lead to a better understanding of central dopaminergic systems.

\section{References}

Alexander, G. M., R. J. Schwartzman, R. D. Bell, J. Yu, and A. Renthal (1981) Quantitative measurement of local cerebral metabolic rate for glucose utilizing tritiated 2-deoxyglucose. Brain Res. 223: 59-67.

Ben-Ari, Y., R. E. Zigmond, and K. E. Moore (1975) Regional distribution of tyrosine hydroxylase, norepinephrine, and dopamine within the amygdaloid complex of the rat. Brain Res. 87: 96-101.

Berger, B., J. P. Tassin, G. Blanc, M. A. Moyne, and A. M. Thierry (1974) Histochemical confirmation for dopaminergic innervation of the rat cerebral cortex after destruction of the noradrenergic ascending pathways. Brain Res. 81: 332-337.

Berger, B., A. M. Thierry, J. P. Tassin, and M. A. Moyne (1976) Dopaminergic innervation of the rat prefrontal cortex: A fluorescence histochemical study. Brain Res. 106: 133-145.

Billard, W., V. Ruperto, G. Crosby, L. C. Iorio, and A. Barnett (1984) Characterization of the binding of ${ }^{3} \mathrm{H}-\mathrm{SCH} 23390$, a selective D-1 receptor antagonist ligand, in rat striatum. Life Sci. 35: 1885-1893.

Bockaert, J., J. P. Tassin, A. M. Thierry, J. Glowinski, and J. Premont (1977) Characteristics of dopamine and beta-adrenergic sensitive adenylate cyclase in the frontal cerebral cortex of the rat. Comparative effects of neuroleptics on frontal cortex and striatal dopamine sensitive adenylate cyclases. Brain Res. 122: 71-86.

Bjorklund, A., O. Lindvall, and A. Nobin (1975) Evidence of an incerto-hypothalamic dopamine neurone system in the rat. Brain Res. 89: $29-42$.

Christensen, A. V., J. Arnt, J. Hyttel, J.-J. Larsen, and O. Svendsen (1984) Pharmacological effects of a specific dopamine D-1 antagonist SCH 23390 in comparison with neuroleptics. Life Sci. 34: 1529-1540.

Cote, T. E., C. W. Crewe, and J. W. Kebabian (1981) Stimulation of the $\mathrm{D}-2$ dopamine receptor in the intermediate lobe of the rat pituitary gland decreases the responsiveness of the beta-adrenoceptor: Biochemical mechanisms. Endocrinology 108: 420-426.

Creese, I., and S. E. Leff (1982) Dopamine receptors: A classification. J. Clin. Psychopharmacol. 2: 329-335.

Creese, I., R. Schneider, and S. H. Snyder (1977) ${ }^{3} \mathrm{H}-$ Spiroperidol labels dopamine receptors in pituitary and brain. Eur. J. Pharmacol. 46: 377-381.

Creese, I., D. R. Sibley, M. W. Hamblin, and S. E. Leff (1983) The classification of dopamine receptors: Relationship to radioligand binding. Annu. Rev. Neurosci. 6: 43-71.

Dawson, T. M., D. R. Gehlert, H. I. Yamamura, A. Barnett, and J. K. Wamsley (1985a) D-1 dopamine receptors in the rat brain: Autoradiographic localization using [ $\left.{ }^{3} \mathrm{H}\right] \mathrm{SCH} 23390$. Eur. J. Pharmacol. 108: 323-325.

Dawson, T. M., D. R. Gehlert, and J. K. Wamsley (1985b) Quantitative autoradiographic demonstration of high and low affinity agonist binding of D-2 dopamine receptors. Clin. Res. 33: 69A.

DeVeaugh-Geiss, J. (1982) Tardive dyskinesia: Phenomenology, pathophysiology, and pharmacology. In Tardive Dyskinesia and Re- 
lated Involuntary Movement Disorders, J. DeVeaugh-Geiss, ed., pp. 1-19, John Wright PSG, Littleton, MA.

Fallon, J. H., D. A. Koziell, and R. Y. Moore (1978) Catecholamine innervation of the basal forcbrain. II. Amygdala, suprarhinal cortex and entorhinal cortex. J. Comp. Neurol. 180: 509-552.

Fields, J. Z., T. D. Reisine, and H. I. Yamamura (1977) Biochemical demonstration of dopaminergic receptors in rat and human brain using $\left[{ }^{3} \mathrm{H}\right]$ spiroperidol. Brain Res. 136: $578-584$.

Fuxe, K., T. Hökfelt, O. Johansson, G. Jonsson, P. Lidbrink, and A. Ljungdahl (1974) The origin of the dopamine nerve terminals in limbic and frontal cortex. Evidence for meso-cortico dopamine neurons. Brain Res. 82: 349-355.

Gehlert, D. R., and J. K. Wamsley (1984) Autoradiographic localization of $\left[{ }^{3} \mathrm{H}\right]$ sulpiride binding sites in the rat brain. Eur. J. Pharmacol 98: $311-312$.

Gehlert, D. R., and J. K. Wamsley (1985) Dopamine receptors in the rat brain: Quantitative autoradiographic localization using $\left[{ }^{3} \mathrm{H}\right]$-sulpiride. Neurochcm. Int. 4: 717-723.

Gehlert, D. R., T. M. Dawson, A. Barnett, H. I. Yamamura, and J. K. Wamsley (1986) Autoradiographic localization of dopamine type-1 receptors after labeling with $\left[{ }^{3} \mathrm{H}\right]-\mathrm{SCH} 23390$ in the rat and human brain: Comparison with the distribution of D-2 receptors. In Modulation of Central and Peripheral Transmitter Function, Symposia in Neuroscience, Vol. 3, G. Biggio, P. F. Spano, G. Toffano, and G. L. Gessa, eds., pp. 27-35, FIDIA Research Series, Liviana Press, Padua, Italy.

Gessa, G. L., M. L. Porceddu, M. Collu, G. Mereu, M. Serra, E. Ongini, and G. Biggio (1985) Sedation and sleep induced by high doses of apomorphine after blockage of D-1 receptors by SCH 23390. Eur. J. Pharmacol. 109: 269-274.

Gilbert, C. D., and T. N. Wiesel (1979) Morphology and intracortical projections of functionally characterized neurons in the cat visual cortex. Nature 280: 120-125.

Hicks, P. E., H. Schoemaker, and S. Z. Langer (1984) 5HT-Receptor antagonist properties of SCH 23390 in vascular smooth muscle and brain. Eur. J. Pharmacol. 105: 339-342.

Huff, R. M., and P. B. Molinoff (1985) Assay of dopamine receptors with [alpha- $\left.{ }^{3} \mathrm{H}\right]$ flupenthixol. J. Pharmacol. Exp. Ther. 232: 57-61.

Hyttel, J. (1978a) Effects of neuroleptics on ${ }^{3} \mathrm{H}$-haloperidol and ${ }^{3} \mathrm{H}-$ cis-(Z)-flupenthixol binding and on adenylate cyclase activity in vitro Life Sci. 23: 551-556.

Hyttel, J. (1978b) A comparison of the effect of neuroleptic drugs on the binding of ${ }^{3} \mathrm{H}$-haloperidol and ${ }^{3} \mathrm{H}$-cis-(Z)-flupenthixol and on adenylate cyclase activity in rat striatal tissue in vitro. Prog. NeuroPsychopharmacol. 2: 329-335.

Hyttel, J. (1981) Similarities between the binding of ${ }^{3} \mathrm{H}$-piflutixol and ${ }^{3} \mathrm{H}$-flupentixol to rat striatal dopamine receptors in vitro. Life Sci. 28: 563-569.

Hyttel, J. (1983) SCH 23390-The first selective dopaminc D-1 antagonist. Eur. J. Pharmacol. 91: 153-154.

Iorio, L. C., A. Barnett, F. H. Leitz, V. P. Houser, and C. A. Korduba (1983) SCH 23390, a potential benzazepine antipsychotic with unique interactions on dopaminergic systems. J. Pharmacol. Exp. Ther. 226: 462-468.

Iversen, S. D. (1983) Brown lesions and memory in animals: A reappraisal. In The Physiologic Basis of Memory, A. Deutsch, ed., pp. 139-198, Academic, New York.

Iversen, S. D. (1984) Cortical monoamines and behavior. In Monoamine Innervation of Cerebral Cortex, L. Descarries, T. R. Reader, and H. H. Jasper, eds., pp. 321-349, Liss, New York.

Jastrow, T. R., E. Richfield, and M. E. Gnegy (1984) Quantitative autoradiography of $\left[{ }^{3} \mathrm{H}\right]$ sulpiride binding sites in rat brain. Neurosci. Lett. 51: 47-53.

Kebabian, J. W., and D. B. Calne (1979) Multiple receptors for dopamine. Nature 277: 93-96.

Klemm, N., L. C. Murrin, and M. J. Kuhar (1979) Neuroleptic and dopamine receptors: Autoradiographic localization of $\left[{ }^{3} \mathrm{H}\right]$ spiperone in rat brain. Brain Res. 169: 1-9.

Kuhar, M. J. (1985a) The mismatch problem in receptor mapping studies. Trends Neurosci. 8: 190-191.

Kuhar, M. J. (1985b) Receptor localization with the microscope. In Neurotransmitter Receptor Binding, H. I. Yamamura, S. J. Enna, and M. J. Kuhar, eds., pp. 153-177, Raven, New York.

Kuhar, M. J., and J. R. Unnerstall (1985) Quantitative receptor mapping by autoradiography: Some current technical problems. Trends Neurosci. 8: 49-53.
Kupfermann, I. (1981) Hypothalamus and limbic system. II: Motivation. In Principles of Neuroscience, E. R. Kandel and J. H. Schwartz, eds., pp. 450-460, Elsevier, New York.

Laduron, P. M., P. F. M. Janssen, and J. E. Leysen (1982) In vivo binding of $\left[{ }^{3} \mathrm{H}\right]$ ketanserin on serotonin $\mathrm{S}_{2}$-receptors in rat brain. Eur. J. Pharmacol. 81: 43-48.

Leff, S. E., M. W. Hamblin, and I. Creese (1985) Interactions of dopamine agonists with brain $\mathrm{D}_{1}$ receptors by ${ }^{3} \mathrm{H}$-antagonists. Evidence for the presence of high and low affinity agonist-binding states. Mol. Pharmacol. 27: 171-183.

LeVay, S., and H. Sherk (1981) The visual claustrum of the cat. 1. Structure and connections. J. Neurosci. 1: 956-980.

Leysen, J. E., F. Awouters, L. Kennis, P. M. Laduron, J. Vandenberk, and P. A. J. Janssen (1981) Receptor binding profile of R 41468 , a novel antagonist at 5-HT, receptors. I ife Sci. 28: 1015-1022.

Leysen, J. E., C. J. E. Niemegeers, J. M. VanNueten, and P. M. Laduron (1982) $\left[{ }^{3} \mathrm{H}\right]$ ketanserin (R 41468 ), a selective ${ }^{3} \mathrm{H}$-ligand for serotonin receptor binding sites. Mol. Pharmacol. 21: 301-314.

Leysen, J. E., W. Gommeren, and F. DeClerck (1983) Demonstration of $\mathrm{S}_{2}$-receptor binding sites on cat blood platelets using [ $\left.{ }^{3} \mathrm{H}\right]$-ketanserin. Eur. J. Pharmacol. 88: 125-130.

Lindvall, O., and A. Bjorklund (1974) The organization of the ascending catecholamine neuron systems in the rat brain as revealed by the glyoxylic acid method. Acta Physiol Scand. Suppl. 412: 1-48.

Lindvall, O., and A. Bjorklund (1983) Dopamine- and norepinephrine-containing neuron systems: Their anatomy in the rat brain. In Chemical Neuroanatomy, P. C. Emson, ed., pp. 229-255, Raven, New York.

Lindvall, $O$., and A. Bjorklund (1984) General organization of cortical monoamine systems. In Monoamine Innervation of Cerebral Cortex L. Descarries, T. R. Reader, and H. H. Jasper, eds., pp. 9-40, Liss, New York.

Lindvall, O., and U. Stenevi (1978) Dopamine and noradrenaline neurons projecting to the septal area in the rat. Cell Tissue Res. 190: 383-407.

Lindvall, O., A. Bjorklund, R. Moore, and U. Stenevi (1974) Mesencephalic dopamine neurons projecting to neocortex. Brain Res. 81: 325-331.

Mailman, R. B., D. W. Schulz, M. H. Lewis, L. Staples, H. Rollema, and D. L. Dehaven (1984) SCH-23390: A selective $D_{1}$ dopamine antagonist with potent $\mathrm{D}_{2}$ behavioral actions. Eur. J. Pharmacol. 101: 159-160.

Martres, M. P. M. L. Bouthenet, N. Sales, P. Sokoloff, and J. C. Schwartz (1985a) Widespread distribution of brain dopamine receptors evidenced with [ ${ }^{125}$ I] Iodosulpiride, a highly selective ligand. Science 228 : $752-755$.

Martres, M. P., N. Sales, M. L. Bonthenet, and J. C. Schwartz (1985b). Localisation and pharmacological characterization of D-2 dopamine receptors in rat cercbral ncocortex and ccrebellum using [ $\left.{ }^{125} 1\right]-$-Iodosulpride. Eur. J. Pharmacol. 118: 211-219.

Mishra, R. K., C. Demirjam, K. Katzman, and M. H. Makman (1975) A dopamine sensitive adenylate cyclase in anterior limbic cortex and mesolimbic region of primate brain. Brain Res. 96: 395-399.

Molloy, A. G., and J. L. Waddington (1985) Sniffing, rearing and locomotor responses to the D-1 dopamine agonist R-SK\&F 38393 and to apomorphine: Differential interactions with the selective D-1 and D-2 antagonist SCH 23390 and metoclopramide. Eur. J. Pharmacol. 108: 305-308.

Moore, R. Y., and F. E. Bloom (1978) Central catecholamine neuron systems: Anatomy and physiology of the dopamine systems. Annu. Rev. Neurosci. 1: 129-169.

Moore, R. Y., and N. J. Lenn (1972) A retino hypothalamic projection in the rat. J. Comp. Neurol. 146: 1-14.

Morgan, D. G., J. O. Marcusson, and C. E. Finch (1984) Contamination of serotonin-2 binding sites by an alpha-1 adrenergic component in assays with $\left[{ }^{3} \mathrm{H}\right]$ spiperone. Life Sci. $34: 2507-2514$

Munson, P. J., and D. Rodbard (1980) Ligand: A versatile computerized approach for characterization of ligand-binding systems. Anal. Biochem. 107: 220-239.

Murrin, L. C. (1983) Characteristics of ${ }^{3} \mathrm{H}$-cis-flupenthixol binding in rat striatum. Life Sci. 33: 2179-2186.

Murrin, L. C., and M. J. Kuhar (1979) Dopamine receptors in the rat frontal cortex: an autoradiographic study. Brain Res. 177: 279-285.

O'Connor, S. E., and R. A. Brown (1982) The pharmacology of sulpiride-a dopamine receptor antagonist. Gen. Pharmacol. 13: 185193. 
Ohlstein, E. H., and B. A. Berkowitz (1985) SCH 23390 and SK\&F 83566 are antagonists at vascular dopamine and serotonin receptors. Eur. J. Pharmacol. 108: 205-208.

Onali, P., M. C. Olianas, and G. L. Gessa (1984) Selective blockade of dopamine D-1 receptors by SCH 23390 discloses striatal dopamine D-2 receptors mediating the inhibition of adenylate cyclase in rats. Eur. J. Pharmacol, 99: 127-128.

Onali, P., J. P. Schwartz, and E. Costa (1981) Dopaminergic modulation of adenylate cyclase stimulation of vasoactive intestinal peptide (VIP) in anterior pituitary. Proc. Natl. Acad. Sci. USA 78: 65316534.

Palacios, J. M., and J. K. Wamsley (1984) Catecholamine receptors. In Handbook of Chemical Neuroanatomy. Vol. 3: Classical Transmitters and Transmitter Receptors in the CNS, Part II, A. Bjorklund, T. Hökfelt, and M. J. Kuhar, eds., pp. 325-351, Elsevier, Amsterdam.

Palacios, J. M., D. L. Niehoff, and M. J. Kuhar (1981a) [ $\left.{ }^{3} \mathrm{H}\right]$-spiperone binding sites in the brain: Autoradiographic localization of multiple receptors. Brain Res. 213: 277-289.

Palacios, J. M., J. K. Wamsley, and M. J. Kuhar (1981b) The distribution of histamine $\mathrm{H}_{1}$-receptors in the rat brain: An autoradiographic study. Neuroscience 6: 15-37.

Paxinos, G., and C. Watson (1982) The Rat Brain in Stereotaxic Coordinates, Academic, New York.

Pazos, A., and J. M. Palacios (1985) Quantitative autoradiographic mapping of serotonin receptors in the rat brain. I. Serotonin-1 receptors. Brain Res. 346: 205-230.

Pazos, A., R. Cortes, and J. M. Palacios (1985) Quantitative autoradiographic mapping of serotonin receptors in the rat brain. II. Serotonin-2 receptors. Brain Res. 346: 231-249.

Plantje, J. F., F. J. Davis, H. A. Hansen, and J. C. Stoof (1984a) SCH 23390 blocks D-1 and D-2 dopamine receptors in rat neostriatum in vitro. Naunyn Schmiedebergs Arch. Pharmacol. 327: 180-182.

Plantje, J. F., H. A. Hansen, F. J. Daus, and J. C. Stoof (1984b) The effects of SCH 23390, YM 09151-2, (+)- and (-)-3-PPP and some classical neuroleptics on D-1 and D-2 receptors in rat neostriatum in vitro. Eur. J. Pharmacol. 105: 73-83.

Rainbow, T. C., A. Biegon, and D. J. Berck (1984) Quantitative receptor autoradiography with tritium labeled ligands: Comparison of biochemical and densitometric measurements. J. Neurosci. Methods 11: 231-241

Rupniak, N. M. J., P. Jenner, and C. D. Marsden (1983) The effect of chronic neuroleptic administration on cerebral dopamine receptor function. Life Sci. 32: 2289-2311.

Sanides, D., and C. S. Buchholtz (1979) Identification of the projection from the visual cortex to the claustrum by anterograde axonal transport in the cat. Exp. Brain Res. 34: 197-200.

Scatton, B., and A. Dubois (1985) Autoradiographic localization of D-1 dopamine receptors in the rat brain with [ $\left.{ }^{3} \mathrm{H}\right]$ SKF 38393. Eur. J. Pharmacol. 111: 145-146.

Schulz, D. W., S. D. Wyrick, and R. B. Mailman (1985) [ $\left.{ }^{3} \mathrm{H}\right] \mathrm{SCH}$ 23390 has the characteristics of a dopamine receptor ligand in the rat central nervous system. Eur. J. Pharmacol. 106: 211-212.

Seeman, P. (1980) Brain dopamine receptors. Pharmacol. Rev. 32: 229-313.

Sokoloff, P., M. Brann, K. Redouane, M. P. Martres, J. C. Schwartz, M. L. Bouthenet, N. Sales, A. Mann, P. Hamdi, C. G. Wermuth, J. Roy and J. L. Morgat (1985) The use of $\left[{ }^{3} \mathrm{H}\right](-)$-DO710 as selective dopaminergic ligand for binding and autoradiographic studies. Eur. J. Pharmacol. 107: 243-251.

Stoof, J. C., and J. W. Kebabian (1982) Independent in vitro regulation by the D-2 dopamine receptor of dopamine-stimulated efflux of cyclic AMP and $\mathrm{K}^{+}$-stimulated release of acetylcholine from rat neostriatum. Brain Res. 250: 263-270.

Stoof, J. C., and J. W. Kebabian (1984) Two dopamine receptors: Biochemistry, physiology and pharmacology. Life Sci. 35: 2281-2296.

Tassin, J. P., A. M. Thierry, G. Blanc, and J. Glowinski (1974) Evidence for a specific uptake of dopamine by dopaminergic terminals of the rat cerebral cortex. Naunyn Schmiedebergs Arch. Pharmacol. 282: 239-244.

Tassin, J. P., L. Velley, L. Stinus, G. Blanc, J. Glowinski, and A. M. Thierry (1975) Development of cortical and nigro-neostriatal dopaminergic systems after destruction of central noradrenergic neurones in foetal or neonatal rats. Brain Res. 83: 93-106.

Tassin, J. P., J. Bockaert, G. Blanc, L. Stinus, A. M. Thierry, S. Lavielle, J. Premont, and J. Glowinski (1978) Topographical distribution of dopaminergic innervation and dopaminergic receptors of the anterior cerebral cortex of the rat. Brain Res. 154: 241-251.

Tassin, J. P., H. Simon, D. Herve, G. Blanc, M. Le Moal, J. Glowinski, and J. Bockaert (1982) Non-dopaminergic fibers may regulate dopamine-sensitive adenylate cyclase in the prefrontal cortex and nucleus accumbens. Nature 295: 696-698.

Theodorou, A., M. Crockett, P. Jenner and C. D. Marsden (1979) Specific binding of $\left[{ }^{3} \mathrm{H}\right]$-sulpiride to rat striatal preparations. J. Pharm. Pharmacol. 31: 424-426.

Thierry, A. M., G. Blanc, A. Sobel, L. Stinus, and J. Glowinski (1973a) Dopaminergic terminals in the rat cortex. Science 182: 499-501.

Thierry, A. M., L. Stinus, G. Blanc, and J. Glowinski (1973b) Some evidence for the existence of dopaminergic neurons in the rat cortex. Brain Res. 50: 230-234.

Thierry, A. M., J.-P. Tassin, and J. Glowinski (1984) Biochemical and electrophysiological studies of the mesocortical dopamine system. In Monoamine Innervation of Cerebral Cortex, L. Descarries, T. R. Reader, and H. H. Jasper, eds., pp. 233-261, Liss, New York.

Toga, A. W., and R. C. Collins (1981) Metabolic response of optic centers to visual stimuli in the albino rat: Anatomical and physiological considerations. J. Comp. Neurol. 199: 443-464.

Tork, I., and S. Turner (1981) Histochemical evidence for a catecholaminergic (presumably dopaminergic) projection from the ventral mesencephalic tegmentum to visual cortex in the cat. Neurosci. Lett. 24: 215-219.

Unnerstall, J. R., D. L. Niehoff, M. J. Kuhar, and J. M. Palacios (1982) Quantitative receptor autoradiography using [ $\left.{ }^{3} \mathrm{H}\right]$ Ultrofilm: Application to multiple benzodiazepine receptors. J. Neurosci. Methods 6: 59-73.

Von Hungen, K., and S. Roberts (1973) Adenylate cyclase receptors for adrenergic neurotransmitters in the rat cerebral cortex. Eur. J. Biochem. 36: 391-403.

Weiland, G. A., and P. B. Molinoff (1981) Quantitative analysis of drug-receptor interactions. I. Determination of kinetic and equilibrium properties. Life Sci. 29: 313-330.

Woodruff, G. N., and S. B. Freedman (1981) Binding of $\left[{ }^{3} \mathrm{H}\right]$ sulpiride to purified rat striatal synaptic membranes. Neuroscience 6: 407-410.

Wurtz, R. H., and J. E. Albano (1980) Visual-motor function of the primate superior colliculus. Annu. Rev. Neurosci. 3: 189-226. 